\title{
Mutual Fund Liquidity Management, Stock Liquidity, and Corporate Disclosure
}

\author{
Liwei Weng* \\ W. P. Carey School of Business \\ Arizona State University
}

First Draft: October 27, 2019

This Draft: July 14, 2020

\begin{abstract}
This study presents the first evidence that mutual fund liquidity management affects both stock liquidity and information disclosure of portfolio firms. Using a difference-indifferences approach that exploits a proposal by the U.S. Securities and Exchange Commission (SEC) as an exogenous shock to mutual fund liquidity management, I find causal evidence that mutual fund liquidity management improves liquidity of underlying stocks. The liquidity improvement is more pronounced when mutual funds have stronger incentives to improve portfolio liquidity and more resources to influence firms, and when portfolio firms have lower stock liquidity and higher information asymmetry prior to the SEC proposal. I further show that mutual funds may exert pressure on portfolio firms to improve their disclosure as a channel to improve stock liquidity. Overall, the results indicate that liquidity management at the fund level has important implications for stock liquidity and information disclosure of portfolio firms.
\end{abstract}

Keywords: mutual fund liquidity management; stock liquidity; corporate disclosure. JEL Classifications: G23; D40; M41; D82.

\footnotetext{
* Liwei Weng is at School of Accountancy, W. P. Carey School of Business, Arizona State University. Email: Liwei.Weng@ASU.edu. I thank my dissertation committee members Stephen Hillegeist (co-chair), Shawn Huang (co-chair), and Yinghua Li for their tremendous support and valuable advice. I am grateful for helpful comments from Badryah Alhusaini, Jenny Brown, Xia Chen, Agnes Cheng, Qiang Cheng, Lucile Faurel, Zhaoyang Gu, Artur Hugon, Steve Kaplan, Bin Ke, David Kenchington, Phillip Lamoreaux, Ji-Chai Lin, Summer Liu, Shuqing Luo, Michal Matejka, David Reeb, Christina Ruiz, Srinivasan Sankaraguruswamy, Albert Tsang, Roger White, Guochang Zhang, Liandong Zhang, Wei Zhang, and seminar participants at Arizona State University, Hong Kong Baptist University, National University of Singapore, Singapore Management University, The Chinese University of Hong Kong, The Hong Kong Polytechnic University, and The University of Hong Kong. I thank Bill McDonald for sharing his insights into textual analysis, Steven Orpurt for information about mutual fund liquidity management in practice when he was a vice president and portfolio manager at Franklin Asset Management, and a former portfolio manager at Franklin Templeton Investments for interpretations of the mutual fund liquidity management regulation. I gratefully acknowledge financial support from W. P. Carey School of Business. All remaining errors are my own.
} 


\section{INTRODUCTION}

Mutual funds constantly face redemptions by investors. Fire sales of underlying assets in mutual fund portfolios happen when mutual funds do not have enough cash on hand or liquid securities readily available to be converted into cash to satisfy shareholder redemption requests. As Coval and Stafford (2007) document, fire sales by mutual funds adversely affect mutual fund performance and prices of stocks held by mutual funds. Therefore, the liquidity of portfolios is important to mutual funds. Maintaining liquid portfolios has become increasingly important since the financial crisis in 2007-2009 during which regulators and practitioners raised concerns on whether mutual fund portfolios have enough liquidity to process fund outflows and guard against the potential for investor runs (i.e., widespread withdrawals). To date, academic research on mutual fund liquidity management has focused on the ways in which mutual funds manage liquidity and the effect of liquidity management on fund performance. ${ }^{1}$ However, the impact of fund liquidity management (at the fund level) on underlying stocks (at the stock level) does not receive much attention. To fill this void, I examine whether mutual fund liquidity management causally affects (1) the liquidity of underlying stocks and (2) corporate disclosure of portfolio firms (as a possible mechanism for (1)). ${ }^{2}$

Portfolio liquidity depends on the average liquidity of a portfolio's constituents and the mutual fund's cash holdings. There are two ways for a mutual fund to improve portfolio liquidity: holding more cash and selling illiquid stocks. However, both solutions are costly.

\footnotetext{
${ }^{1}$ For example, Chernenko and Sunderam (2016) examine the use of cash, Agarwal and Zhao (2019) examine the use of interfund lending, Witmer (2019) examines the use of internal money market funds, and Ren (2019) examines the use of redemptions in kind in the mutual fund liquidity management; Simutin (2014) examines the effect of cash holdings on mutual fund performance.

${ }^{2}$ A mutual fund invests in a portfolio of securities. A portfolio firm in this paper means a firm whose shares are held by a mutual fund. I use the terms "portfolio firm" and "underlying stock" interchangeably.
} 
First, holding too much cash adversely affects fund performance by forgoing potentially profitable investment opportunities. Consistent with this argument, Wermers (2000) finds that cash holdings significantly contribute to underperformance of mutual funds. Second, by reducing their holdings of illiquid stocks, mutual funds may incur opportunity costs associated with foregone investment opportunities. Thus, both solutions can erode fund performance. ${ }^{3}$ Given these downsides, mutual funds seek less costly approaches to improve liquidity management. One possible approach is to pressure portfolio firms to improve their own liquidity. Edison, a large investment research and consulting firm for institutional investors, said on August 7, 2019 that mutual funds that insisted portfolio firms maintain and promote stock liquidity for mutual fund liquidity management were likely winners. ${ }^{4}$ Mutual funds can exert their influence through multiple channels such as direct intervention (e.g., shareholder votes), voting with their feet (e.g., exit), and informal communications with firms' directors and managers (Duan and Jiao 2016; Edmans et al. 2013; McCahery et al. 2016). For example, DSP Mutual Fund mentioned in their 2019 annual report that they voted for some corporate activities because these activities would improve portfolio firms' stock liquidity. ${ }^{5}$

Identifying the causal impacts of mutual fund liquidity management on stock liquidity and corporate disclosure of portfolio firms is difficult. A positive relation between mutual fund liquidity management and stock liquidity could be driven by omitted variables that simultaneously cause funds to manage portfolio liquidity and pick liquid stocks. In

\footnotetext{
${ }^{3}$ In addition, Zeng (2017) theoretically shows that selling illiquid assets to improve portfolio liquidity can induce shareholder runs, which can in turn distort fund liquidity management.

4 Please see https://www.edisongroup.com/investment-themes/_post-woodford-a-spotlight-on-smallercompany-liquidity/.

${ }^{5}$ The annual report is available on https://www.dspim.com/docs/default-source/annual-reports/dsp-openended-ar-2019.pdf.
} 
addition, mutual fund liquidity management is unobservable to outsiders.

To overcome these empirical challenges, I explore a shock to mutual fund liquidity management and employ a difference-in-differences (DID) research design to evaluate the relation between mutual fund liquidity management and stock liquidity. My identification strategy is based on a regulatory proposal that creates an exogenous increase in mutual fund liquidity management. On September 22, 2015, the Securities and Exchange Commission (SEC) proposed a new rule to promote effective mutual fund liquidity risk management. ${ }^{6}$ This proposed rule requires each mutual fund to (1) establish a liquidity risk management program, (2) classify the liquidity level of each portfolio asset based on a few factors such as bid-ask spreads, (3) disclose the liquidity of fund holdings to the public, (4) determine the minimum percentage of liquid holdings, and (5) stop acquiring illiquid assets when illiquid holdings are more than $15 \%$ of a fund's net assets. These liquidity requirements can cause an exogenous increase in mutual fund liquidity management for several reasons. First, mutual funds need to improve portfolio liquidity to avoid fund outflows, as fund investors may be concerned about the liquidity of their funds when portfolio liquidity becomes public information. Second, mutual funds need to improve portfolio liquidity to meet the requirements of minimum liquid holdings and maximum illiquid holdings. I expect that mutual funds increase their liquidity management before the proposal takes effect so that they can report high levels of liquidity by the time they are required to make their public disclosure. While this SEC proposal affects every mutual fund, the amount of pressure portfolio firms receive will vary with the level of mutual fund ownership. Thus, my treatment group consists of firms with high mutual fund ownership

\footnotetext{
${ }^{6}$ I explain why I choose the proposal date instead of the adopted date as the event date in Section 3.1.
} 
(i.e., above-median ownership) and my control group consists of firms with low mutual fund ownership (i.e., below-median ownership). ${ }^{7}$

I first examine the effect of mutual fund liquidity management on stock liquidity of portfolio firms. I use two measures of stock liquidity, the Amihud (2002) liquidity measure and the bid-ask spread, which have been widely used in the accounting and finance literatures. Moreover, the SEC directly incorporates these two measures into their proposal for liquidity requirements. ${ }^{8}$ Consistent with my hypothesis, I find evidence that relative to control firms, treatment firms improve their stock liquidity (the Amihud measure) by almost $25 \%$ following the SEC proposal. This causal effect is both statistically and economically significant. I obtain similar results using the bid-ask spread to measure stock liquidity. ${ }^{9}$ Together, these results show that mutual fund liquidity management improves the liquidity of underlying portfolio stocks.

Next, I conduct several tests to analyze cross-sectional variations in the effect of mutual fund liquidity management on stock liquidity. First, mutual funds holding illiquid portfolios are expected to have stronger incentives to increase their liquidity management following the SEC's proposal than funds holding liquid portfolios. Consistent with this argument, I find the results are concentrated among mutual funds with low portfolio

\footnotetext{
${ }^{7}$ The control group includes firms with zero mutual fund ownership. All my results are robust to two alternative treatment variables: (1) a continuous treatment variable (i.e., mutual fund ownership); (2) an alternative binary treatment variable that equals one if mutual fund ownership is greater than 0 .

${ }^{8}$ The Amihud liquidity measure is used by the SEC in the proposal to measure stock liquidity. In the proposal, the SEC states that "Liquidity for individual equity positions is calculated using the Amihud liquidity measure because it is a widely accepted liquidity measure." The bid-ask spread is used by the SEC in the proposed rule as one of several factors that mutual funds are required to consider in the liquidity classification requirement.

${ }^{9}$ My results are robust to several alternative measures of stock liquidity, including turnover and dollar volume. The latter is another factor that mutual funds are required by the SEC proposal to consider when measuring the liquidity of underlying stocks.
} 
liquidity. This finding provides further evidence that it is mutual funds' liquidity concerns that drive the relation between mutual fund liquidity management and stock liquidity.

Second, index funds follow specific stock indexes. As such, when disclosing liquidity of each portfolio stock, index funds have a lower likelihood to be penalized by the SEC and investors for holding many illiquid stocks than non-index funds given index funds' limited flexibility in their portfolio choices. Therefore, index funds are less concerned about their disclosed liquidity of each individual stock than non-index funds. In addition, index funds have highly diversified holdings by design, so it is easier for them to meet this proposal's rules such as the $15 \%$ illiquid stock threshold than non-index funds. Together, index funds have fewer incentives to improve stock liquidity. I expect and find that the effect of the regulatory shock on stock liquidity is more pronounced among portfolio firms of non-index funds that have more incentives to improve stock liquidity.

Third, the ability of mutual funds to influence portfolio firms depends on the level of resources they have. While some funds manage their assets internally, others outsource some or all of funds to external asset management companies. These external asset management companies often allocate fewer resources to these outsourced funds compared to their own in-house funds, and fund families do not have direct control over the external resources devoted to their outsourced funds (Chen et al. 2013; Chuprinin et al. 2015). As resources are needed to communicate with portfolio firms and express their liquidity concerns, outsourced funds may be less willing or less able to pressure portfolio firms. Consistent with this argument, I find that the effect of mutual fund liquidity management on stock liquidity is driven by in-house funds.

In addition to investigating cross-sectional differences among mutual funds, I also 
analyze cross-sectional heterogeneities among portfolio firms. The extent to which mutual funds can improve stock liquidity of their portfolio firms depends on the existing levels of individual stocks' liquidity and information asymmetry. It is unlikely that mutual funds would be able to achieve significant improvements in stock liquidity when firms already have high stock liquidity and transparent information environments. Consistent with this prediction, I find the effect of mutual fund liquidity management on stock liquidity is more pronounced when portfolio firms have lower stock liquidity, lower analyst coverage, or smaller market capitalization prior to the regulatory proposal.

Finally, I explore a channel through which mutual fund liquidity management influences firm-level liquidity. Extant research documents that information asymmetry is an important factor contributing to stock illiquidity (e.g., Diamond and Verrecchia 1991; Vayanos and Wang 2013). Corporate disclosure is often viewed as a remedy for information asymmetry in the capital market. ${ }^{10}$ Anecdotal evidence shows that mutual funds can directly influence portfolio firms' disclosure practices. For example, Blackrock mentioned in their 2017 corporate governance report that when a portfolio firm's disclosure was not enough, they would engage with the company to encourage a change in disclosure practices. Anecdotal evidence also shows that one of optimal responses from portfolio firms when mutual funds demand more stock liquidity for liquidity management is to redouble efforts to ensure there is an adequate and fair disclosure to the market. ${ }^{11}$ Therefore, I expect that (1) mutual funds may directly pressure firms to increase disclosure to improve

\footnotetext{
${ }^{10}$ Please see Balakrishnan et al. (2014), Bushman and Indjejikian (1995), Diamond (1985), Diamond and Verrecchia (1991), Graham et al. (2005), and Schoenfeld (2017).

11 Please see https://www.edisongroup.com/investment-themes/ post-woodford-a-spotlight-on-smallercompany-liquidity/.
} 
firm-level stock liquidity and (2) firms choose to increase disclosure in response to pressure by mutual funds to increase liquidity if mutual funds do not specifically request the use of disclosure to increase liquidity. Consistent with this expectation, I find that relative to control firms, treatment firms are more likely to provide management earnings forecasts and those forecasts, on average, are more precise. I also find that relative to control firms, treatment firms are more likely to hold conference calls and those calls are easier for market participants to understand. Furthermore, mandatory quarterly reports (10-Qs) of treatment firms are easier for investors to read than those of control firms subsequent to the exogenous shock.

This study makes at least five contributions to the literature. First, it contributes to the liquidity literature by showing that mutual fund liquidity management can influence the stock liquidity of portfolio firms. ${ }^{12}$ Second, this study contributes to the disclosure literature. This literature finds that corporate disclosure is affected by factors related to shareholders, directors, analysts, and managers, such as shareholder litigation (Bourveau et al. 2018; Rogers and Van Buskirk 2009) and managers' styles (Bamber et al. 2010). This paper extends this line of research by identifying a new determinant (liquidity management by mutual funds) that can influence corporate disclosure.

Third, my results have important implications for regulators. This paper is the first to evaluate the SEC rule on regulating mutual fund liquidity and provides evidence for regulators not only in the U.S. but also in other countries that are considering introducing

\footnotetext{
${ }^{12}$ Please see Vayanos and Wang (2013) for a review on the liquidity literature.
} 
mutual fund liquidity management regulations. ${ }^{13}$ The evidence documented in this paper indicates that the regulation is effective in inducing funds to improve portfolio liquidity, and one way through which funds accomplish it is by pushing portfolio firms for more transparent corporate disclosures.

Fourth, this paper contributes to our understanding of whether and why mutual funds influence corporate decisions. Recent studies find that mutual funds and institutional investors can influence portfolio firms in many areas, such as corporate governance (Appel et al. 2016; Schmidt and Fahlenbrach 2017), stock liquidity (Boone and White 2015), and corporate disclosure (Boone and White 2015). These studies focus on mutual funds or institutional investors as a whole and show that they affect portfolio firms' stock liquidity and corporate disclosure for monitoring purpose (e.g., Boone and White 2015). I contribute to this literature by identifying a new purpose (liquidity management purpose) and showing that a particular aspect of mutual funds, i.e., mutual fund liquidity management, can improve the liquidity of underlining stocks through its effect on corporate disclosure.

Finally, my paper contributes to the mutual fund literature by identifying one of tools that mutual funds use to manage portfolio liquidity. My results improve our understanding of mutual fund liquidity management in practice, which is often unobservable to outsiders.

\section{LITERATURE REVIEW AND HYPOTHESIS DEVELOPMENT}

\subsection{Hypothesis: Stock Liquidity}

Under the Investment Company Act of 1940, a mutual fund must pay redemption

\footnotetext{
${ }^{13}$ For example, Britain's Financial Conduct Authority is considering new rules to strengthen mutual fund liquidity management, especially after LF Woodford Equity Income Fund failed to meet redemption requests in June 2019.
} 
proceeds to a fund investor in a timely manner, no more than seven days after receiving a redemption request. ${ }^{14}$ The actual practice by mutual funds is even more timely as compared to the regulation. ${ }^{15}$ To achieve fast redemption, mutual funds often need to keep enough cash. When lacking cash or liquid securities that are readily convertible to cash, mutual funds have to sell their assets potentially at a large discount (fire sales) if their trades move prices lower in exchange for cash to process redemption requests. Coval and Stafford (2007) investigate mutual fund fire sales and find that mutual funds experiencing large redemptions tend to sell existing positions at transaction prices that are substantially below fundamental values. Concerns about fire sales were amplified during the financial crisis period of 2007-2009 when stock liquidity greatly decreased. The SEC views fund liquidity as a top priority for mutual funds (Hanouna et al. 2015). As a result, there has been increased regulatory, academic, and practitioner attention being directed to the mutual fund liquidity management and specifically, whether mutual fund portfolios have enough liquidity to process fund outflows and guard against the potential for investor runs.

Prior literature examines several liquidity management tools used by mutual funds. These tools include cash, interfund lending, ${ }^{16}$ internal money market funds, ${ }^{17}$ redemptions in kind, ${ }^{18}$ credit lines, and so on. Chernenko and Sunderam (2016) find that mutual funds hold cash to accommodate investors' redemption requests. Agarwal and Zhao (2019) study interfund lending and document that interfund lending helps to mitigate fire sales when

\footnotetext{
${ }^{14}$ Please see https://www.sec.gov/fast-answers/answersmfredemptionshtm.html.

15 Please see https://www.sec.gov/dera/staff-papers/white-papers/liquidity-white-paper-09-2015.pdf.

${ }^{16}$ Interfund lending means lending or borrowing activities between funds within a mutual fund family. While the Investment Company Act of 1940 restricts interfund lending, mutual funds can apply for exemptions for internal lending.

${ }^{17}$ Internal money market funds are money market funds held by other funds in the same fund family.

${ }^{18}$ Mutual funds deliver securities instead of cash to fund investors to meet their redemption requests.
} 
there are extreme redemption requests. Witmer (2019) points out that some mutual funds use internal money market funds as a potential cash source of mutual fund liquidity management. Ren (2019) finds that some mutual funds use redemptions in kind. Funds can also use credit lines to meet redemptions (Wermers 2000; Zeng 2017).

While these tools help mutual funds manage their liquidity, they have limitations. With respect to cash, holding cash adversely affects fund performance (e.g., Wermers 2000). In addition, Chernenko and Sunderam (2016) find that mutual funds generally do not hold enough cash for liquidity management. In terms of interfund lending, only $20 \%$ of mutual funds are allowed to use interfund lending (Agarwal and Zhao 2019). With regard to credit lines, Zeng (2017) theoretically demonstrates that using credit lines only temporarily mitigates redemption problems and can induce more severe redemptions in the future. Furthermore, when market liquidity is low, external financing may not be feasible, as banks may not be able to provide promised credit lines to mutual funds (Brunnermeier 2009). Given the limitations of these tools, one way for mutual funds to improve portfolio liquidity may be exerting pressure on portfolio firms to improve their stock liquidity. After all, portfolio liquidity largely depends on the average liquidity of the portfolio's constituents. This liquidity tool (i.e., exerting pressure on portfolio firms to improve liquidity) and the other liquidity tools, while independent, are not mutually exclusive. Mutual funds may use multiple tools together to reach the desired portfolio liquidity levels.

For this "pressure" strategy to work, mutual funds need to have sufficient influence over portfolio firms. Prior literature provides strong evidence that mutual funds have abilities to influence their portfolio firms' corporate decisions. Recent studies find that even passive mutual funds and institutional investors can influence portfolio firms' disclosure 
(Boone and White 2015), governance (Appel et al. 2016; Schmidt and Fahlenbrach 2017), tax planning (Chen et al. 2019; Khan et al. 2017), dividend payout policy (Crane et al. 2016), CEO turnover (Kang et al. 2018), and financing activities (Cao et al. 2018). Taken together, these studies indicate that mutual funds, as large shareholders, should have the abilities to elicit corporate changes, including stock liquidity improvements. It is possible that the effect of mutual fund liquidity management on stock liquidity may be muted. Each liquidity management tool has costs and benefits. Funds will pick the best combinations of these tools, which may not include pressuring firms to improve their stock liquidity. Thus, it is an empirical question regarding whether mutual fund liquidity management affects portfolio firms' stock liquidity. My first hypothesis, stated in the alternative form, is as follows:

H1: Mutual fund liquidity management motivates funds to elicit stock liquidity improvements in portfolio firms.

\subsection{Hypothesis: Cross-Sectional Variation}

The effect of mutual fund liquidity management on stock liquidity may vary crosssectionally with fund characteristics. First, when a mutual fund's portfolio liquidity is already high, the fund is not incentivized to further improve its portfolio liquidity. Thus, I expect the liquidity management effect to be more pronounced among mutual funds with lower existing levels of portfolio liquidity.

Second, mutual funds may find it undesirable to publicly disclose a relatively high percentage of illiquid stocks because these stocks might reflect fund managers' poor stock picking skills. Index funds, however, are less concerned about disclosing liquidity levels of individual stocks because index funds have to follow specific indexes and have less 
flexibility in picking stocks. This implies that index funds have weak incentives to manage liquidity. Furthermore, holdings of index funds are highly diversified (Bushee and Noe 2000), making it easier for index funds to meet this new regulation's liquidity threshold requirements (e.g., 15\% illiquid stocks) than non-index funds. Taken together, the liquidity management effect is expected to be lower for index funds than for non-index funds.

Third, Chen et al. (2013) and Chuprinin et al. (2015) argue that asset management companies provide fewer resources to outsourced funds and treat outsourced funds less favorably relative to in-house funds. Given that exerting pressure on portfolio firms to improve stock liquidity requires mutual funds to devote their resources, I expect that the liquidity management effect is more pronounced for in-house funds than for outsourced funds.

The effect of mutual fund liquidity management may vary cross-sectionally with firm characteristics as well. When portfolio firms have low stock liquidity or high information asymmetry, they have more room to improve their stock liquidity than firms with high stock liquidity or low information asymmetry. Thus, I expect the liquidity management effect to be amplified for firms with low stock liquidity and high information asymmetry (i.e., low analyst coverage and small market capitalization). These discussions lead to the following hypotheses stated in the alternative form:

H2a: The effect of mutual fund liquidity management on stock liquidity is more pronounced for mutual funds that have lower existing levels of portfolio liquidity, that are non-index funds, and that are managed in-house.

H2b: The effect of mutual fund liquidity management on stock liquidity is more pronounced for firms with lower existing levels of stock liquidity, with lower analyst 
coverage, and with smaller market capitalization.

\subsection{Hypothesis: Corporate Disclosure}

Prior theoretical and empirical studies document that information asymmetry is a very important determinant of stock liquidity and one way for firms to increase liquidity is to reduce information asymmetry (e.g., Diamond and Verrecchia 1991; Vayanos and Wang 2013). There is extensive literature on the effects of corporate disclosure on information asymmetry and stock liquidity. Theoretical research has shown that corporate disclosure can improve stock liquidity (Bushman and Indjejikian 1995; Diamond 1985; Diamond and Verrecchia 1991). Consistent with the theoretical prediction, Coller and Yohn (1997) find that management earnings forecasts improve stock liquidity. Brown et al. (2004) find that conference calls are negatively associated with information asymmetry. Recent empirical studies document further causal evidence that corporate disclosure can affect stock liquidity and managers actively use disclosure to improve stock liquidity. Specifically, using a natural experiment that introduces exogenous variation in the supply of public information, Balakrishnan et al. (2014) find that firm managers provide quarterly earnings guidance to improve stock liquidity. Employing a recursive structural equation model of voluntary disclosure, Schoenfeld (2017) points out that there are causal effects of management guidance and $8-\mathrm{K}$ filings on stock liquidity. In addition to voluntary disclosure, mandatory disclosure has been shown to affect stock liquidity. Lee (2012) finds that the readability of mandatory quarterly reports (10-Qs) can affect information asymmetry. Finally, survey evidence also indicates that a strong motivation for voluntary disclosure is to reduce information asymmetry and firm managers confirm that voluntary disclosure effectively improves stock liquidity (Graham et al. 2005). Therefore, I expect 
that mutual funds would focus on corporate disclosure when exerting pressure on portfolio firms to improve stock liquidity. The third hypothesis stated in the alternative form is as follows:

H3: Mutual fund liquidity management increases the frequency of voluntary disclosure and improves the quality of voluntary and mandatory disclosures among portfolio firms.

\section{METHODOLOGY AND DATA}

\subsection{Identification Strategy}

Since mutual fund liquidity management is unobservable, it is difficult to evaluate the relation between mutual fund liquidity management and portfolio firms' stock liquidity and disclosure. In addition, identifying causality is complicated by potential omitted correlated variables and reverse causality concerns. To address these empirical challenges, I adopt the following identification strategy. On September 22, 2015, the Securities and Exchange Commission (SEC) proposed a new rule to promote effective mutual fund liquidity risk management. The rule seeks to reduce the risk that mutual funds will be unable to meet redemption obligations, to mitigate dilution of the interests of mutual fund shareholders, and to enhance disclosure regarding fund liquidity.

The SEC proposal involves several major regulatory changes. First, it requires each mutual fund to establish a liquidity risk management program. Second, each mutual fund needs to classify each of its portfolio assets (e.g., stocks) into one of six liquidity categories based on the number of days within which the asset will be convertible to cash at a price that does not materially affect the value of that asset immediately prior to sale. Third, the proposal requires each mutual fund to disclose information regarding the liquidity of the fund's holdings and its liquidity risk management program. Fourth, each mutual fund needs 
to determine its minimum percentage of liquid holdings and is prohibited from acquiring any less liquid asset if the acquisition will result in the failure of meeting its minimum percentage of liquid holdings. Finally, a mutual fund is required to stop acquiring illiquid assets when illiquid holdings are more than $15 \%$ of net assets. Appendix A provides these requirements in detail.

The SEC proposal regarding mutual fund liquidity management was adopted on October 13, 2016 and became effective on January 17, 2017. The compliance date is December 1, 2018 for large mutual funds and June 1, 2019 for small mutual funds. ${ }^{19}$ I use the release date (i.e., September 22, 2015) of the regulatory proposal as the event date of my analysis for two reasons. First, whenever the SEC proposes a new rule, the perceived probability of adopting the rule in general is high. To the extent that improving mutual fund liquidity and establishing an effective liquidity management program take time, mutual funds have incentives to take actions immediately instead of waiting for the formal adoption of the rule. For example, immediately after the proposal announcement date, State Street Global Advisors started to establish a liquidity risk management project. ${ }^{20}$ However, it took three years for State Street Global Advisors to complete the program. Second, though the SEC will slightly adjust the rules in response to comments they receive during the comment periods, the SEC final rules are often very similar to the proposed rules. That is, proposed rules already contain enough information for mutual funds to take initial actions. Using legislative proposal dates as treatment dates is also common in the literature (e.g., Cohn et al. 2016; De Simone et al. 2019; Lin et al. 2019).

\footnotetext{
${ }^{19}$ Large mutual funds are funds that have net assets of $\$ 1$ billion or more and small mutual funds are funds that have net assets of less than $\$ 1$ billion.

${ }^{20} \mathrm{https}: / /$ www.ssga.com/blog/2019/03/new-sec-liquidity-rules-should-enable-better-risk-management.html.
} 
This proposal is a shock to mutual fund liquidity management and induces funds to improve portfolio liquidity for two reasons. First, mutual funds need to manage portfolio liquidity to meet the proposal's requirements. Second, mutual funds want to have liquid portfolio holdings in the new mandatory liquidity disclosure regime so that fund investors would not withdraw their investment due to liquidity concerns. Thus, this regulatory proposal constitutes an exogenous shock to mutual funds' willingness to improve their portfolio liquidity. Importantly, this shock is arguably exogenous to stock liquidity and corporate disclosure, which allows me to identify the causal effects of mutual fund liquidity management on portfolio firms' stock liquidity and corporate disclosure. I employ a standard difference-in-differences (DID) model. One advantage of using DID in my setting is that DID does not require control firms to be comparable to treatment firms. Instead, DID requires that the changes in outcome variables are similar between treatment firms and control firms prior to the treatment. I examine the validity of this assumption "parallel trends" in the next section. ${ }^{21}$

Specifically, I estimate the following model:

$Y_{i, t}=\alpha+\beta_{1}$ Treat $_{i}+\beta_{2}$ Post $_{t}+\beta_{3}$ Treat $_{i} \times$ Post $_{t}+\beta$ Controls $+F E+\varepsilon_{i, t}$,

where $Y$ is either a stock liquidity variable or a corporate disclosure variable, Treat is an indicator variable taking a value of one if a firm's mutual fund ownership in the last calendar quarter before September 22, 2015 is above the sample median and zero otherwise..$^{22}$ I expect Treat to capture possible differences in stock liquidity and corporate

\footnotetext{
${ }^{21}$ DID does not require the levels of outcome variables to be similar between treatment firms and control firms prior to the treatment.

${ }^{22}$ Prior studies have also used pre-treatment mutual fund ownership as a treatment variable (e.g., Agarwal et al. 2018).
} 
disclosure between the treatment and control groups prior to the SEC mutual fund liquidity management proposal. Post is an indicator variable that equals one if quarter $t$ is after September 22, 2015 and zero otherwise. ${ }^{23}$ It captures the time trend in stock liquidity and disclosure. Treat $\times$ Post is the variable of interest that captures the effect of the SEC proposal on the treatment group. Controls is a vector of control variables, and FE indicates year-quarter fixed effects and either industry fixed effects (based on Fama-French 48 industry classification) or firm fixed effects. Standard errors are corrected for clustering at the firm level. In some model specifications, I do not include the main effect of Post (Treat), because it is absorbed by year-quarter (firm) fixed effects. When I use probit regressions or ordered probit regressions, I do not include firm fixed effects due to the incidental parameter problem. ${ }^{24}$

\subsection{Parallel Trends Assumption}

The key assumption underlying the difference-in-differences framework is the "parallel trends" assumption. This assumption requires that the treatment and control groups have similar trends in the outcome variables during the pre-event period. In other words, this assumption requires that there should be no differences in pre-event trends in stock liquidity between treatment and control firms. As Fang et al. (2014), Lemmon and Roberts (2010), and Luong et al. (2017) note, the parallel trends assumption does not require the level of outcome variables to be identical across the two groups (i.e., treatment and control groups) or across the two periods (i.e., pre-treatment and post-treatment

\footnotetext{
${ }^{23}$ I drop the quarter containing September 22, 2015.

${ }^{24}$ Estimating probit or ordered probit models with firm fixed effects would result in biased and inconsistent point estimates due to the incidental parameter problem (Greene 2012; Lancaster 2000; Neyman and Scott 1948).
} 
periods). To evaluate the reasonableness of the parallel trends assumption, I include two additional indicator variables for observations in the first year and the second year prior to the proposal date and their interaction terms with Post. The results of evaluating the parallel trends assumption are reported in section 4.1.

\subsection{Variables and Data}

\subsubsection{Stock Liquidity and Control Variables}

I use the Amihud (2002) liquidity measure and bid-ask spreads to measure stock liquidity. The Amihud liquidity measure is computed as the ratio of daily absolute returns to the same-day dollar trading volume. It captures price impacts of trades. These two liquidity measures are widely adopted in the accounting and finance literatures. Furthermore, the SEC directly incorporates these two measures into its proposal. Both measures are multiplied by (-1) so that higher values indicate higher stock liquidity. I follow Balakrishnan et al. (2014) and include market capitalization (Size), Stock Return Volatility, and Analyst Coverage as control variables for stock liquidity. Appendix B provides detailed variable definitions.

\subsubsection{Disclosure Variables and Control Variables}

Following prior literature, I measure corporate disclosure using management earnings guidance, conference calls, and quarterly reports. The first disclosure measure, Earnings Guidance, captures the likelihood of issuing management guidance. It is an indicator variable that equals one if a firm issues at least one management quarterly earnings forecast in a given fiscal quarter and zero otherwise. Following Armstrong et al. (2014) and Chen and Vashishtha (2017), I compute the precision of management guidance, Guidance Precision, which equals 4 if the firm issues a point forecast, 3 if a range forecast, 
2 if an open-ended forecast, 1 if a qualitative forecast, and 0 if no forecast. Similarly, I examine the likelihood of conference calls using Conference Call, an indicator variable that equals one if the firm holds at least one conference call in a given fiscal quarter and zero otherwise. Call Readability is the Gunning Fog index of conference call transcripts multiplied by (-1) so that larger values indicate greater readability. Gross File Size is a readability measure of quarterly reports developed by Loughran and Mcdonald (2014). It is the file size of the text document (in megabytes) of the firm's 10-Q filed in a given fiscal quarter. I multiply Gross File Size by (-1) so that higher values of Gross File Size indicate higher readability.

Following prior studies (e.g., Ajinkya et al. 2005; Cassell et al. 2013), I include an extensive set of control variables in disclosure analyses. I control for Stock Return, Stock Return Volatility, B/M, Size, Earnings Volatility, $R \& D$, Analyst Coverage, News, Loss, Analyst Dispersion, External Financing (Bradshaw et al. 2006), Litigation (firm-year ex ante litigation risk based on Kim and Skinner (2012)), and Competition (firm-year competition based on Li et al. (2013)). Please see Appendix B for variable definitions. Continuous variables are winsorized at the 1st and 99th percentiles.

\subsubsection{Data and Descriptive Statistics}

My sample period is from September 22, 2012 to September 22, 2018, including the three-year pre-treatment period and the three-year post-treatment period. The sample used in stock liquidity analyses contains 99,772 stock-quarter observations. In the model specifications with firm fixed effects, singleton firms (i.e., firms with only one observation in the sample) are dropped to avoid underestimating standard errors and overstating statistical significance (Correia 2015; deHaan et al. 2017), leading to 99,435 observations. 
There are 96,852 firm-quarter observations in the disclosure analyses and the exact number of observations varies in each disclosure analysis depending on the specific unit of analysis (e.g., at the forecast level or conference call level) and data availability (e.g., 10-Q readability). I obtain data from CRSP, Compustat, IBES, Thomson Reuters, and EDGAR. I hand collect conference call information from Seeking Alpha and outsourced mutual fund information from the CRSP Mutual Fund database, the Thomson Mutual Fund Holdings database, and mutual funds' SEC filings (e.g., Form ADV). Appendix B describes the data sources.

Table 1 presents the descriptive statistics for variables used in the stock liquidity and disclosure analyses. Log Amihud has a mean of -0.197 and Log Spread has a mean of -0.312. The mean value of Earnings Guidance is 0.11, indicating that the unconditional probability of management quarterly earnings forecasts in my sample is $11 \%$. The unconditional probability of conference calls is $70.6 \%$. The average size of quarterly report text files is 9.666 megabytes.

[Insert Table 1 here]

\section{EMPIRICAL RESULTS}

\subsection{Impact of Mutual Fund Liquidity Management on Stock Liquidity}

Table 2 examines the effect of mutual fund liquidity management on stock liquidity. In Columns (1) and (2), I measure stock liquidity using Log Amihud and Log Spread, respectively. The coefficients on Treat $\times$ Post in both columns are positive and statistically significant at the $1 \%$ level, indicating that the increase in stock liquidity of treatment firms is greater than that of control firms in the post-treatment period. These results support hypothesis $\mathrm{H} 1$ that mutual fund liquidity management motivates funds to elicit stock 
liquidity improvements among portfolio firms. The effect is economically significant as well. Relative to control firms, treatment firms improve their stock liquidity (Log Amihud) by $24.87 \%$ following the SEC proposal..$^{25}$ The stock liquidity improvement is $6.09 \%$ when stock liquidity is measured using Log Spread. ${ }^{26}$ Together, the finding indicates that mutual fund liquidity management, which is previously viewed to be only relevant to mutual funds and fund investors, has a meaningful impact on the liquidity of individual portfolio stocks.

In Columns (3) and (4), I include two additional interaction terms, Treat $\times$ Pre1 and Treat $\times \operatorname{Pre} 2$, to evaluate the parallel trends assumption, where Pre1 and Pre 2 are indicator variables for observations in the first year and the second year prior to the proposal date, respectively ${ }^{27}$ While the coefficients on Treat $\times$ Post remain statistically significant at the $1 \%$ level, the statistically insignificant coefficients on both Treat $\times$ Pre1 and Treat $\times$ Pre 2 indicate that the parallel trends assumption is satisfied.

Treatment firms and control firms have different levels of mutual fund ownership prior to the treatment that may lead to a difference in the outcome variables. Even though this is not a concern in the DID research design given that any distinctions between treatment firms and control firms are differenced out in the estimation, I further include firm fixed effects in the regressions and report the results in Columns (5) and (6). The coefficient estimates on Treat $\times$ Post remain positive and statistically significant at the $1 \%$ level. More importantly, the effect remains economically significant even after controlling for firm fixed effects.

\footnotetext{
${ }^{25} 0.049$ (coefficient) $/|-0.197|($ mean $)=24.87 \%$.

${ }^{26} 0.019$ (coefficient) $/|-0.312|($ mean $)=6.09 \%$.

${ }^{27}$ Post, Pre1, and Pre 2 are omitted from the regressions because they are absorbed by year-quarter fixed effects.
} 
[Insert Table 2 here]

\subsection{Cross-Sectional Analyses}

In this section, I examine cross-sectional variations in the effect of liquidity management across different groups of mutual funds partitioned on funds' liquidity management incentives and abilities, and subsamples of firms sorted separately by their levels of pre-treatment liquidity and information asymmetry.

\subsubsection{Mutual Fund Portfolio Liquidity}

Yan (2008) and Agarwal and Zhao (2019) use the value-weighted average stock liquidity of all stocks held in a mutual fund's portfolio to measure mutual fund portfolio liquidity. The SEC also uses the same method (weighted average of Amihud liquidity) to measure portfolio liquidity in the proposal (SEC 2015). ${ }^{28}$ Following these prior studies and the SEC's proposal, I use the value-weighted average stock liquidity of all stocks in a given mutual fund's portfolio to proxy for mutual fund portfolio liquidity. Specifically, I take the weighted average of Amihud liquidity of all stocks held by a fund to compute this fund's portfolio liquidity:

$$
\text { Portfolio Liquidity }=\sum W_{\text {eight }} \times \text { Stock_Liquidity }_{i},
$$

where $W e i g h t_{i}$ is the weight of stock $i$ in its portfolio, calculated as the dollar amount of holdings in stock $i$ divided by the total dollar amount of the portfolio, and Stock_Liquidity $i$ is measured using Log Amihud of stock $i$.

I divide mutual funds into liquid and illiquid funds based on the median portfolio liquidity measured immediately before the treatment. I calculate each firm's liquid fund

\footnotetext{
28 The SEC explains in the proposal that "average liquidity of a fund's equity positions is defined as the assetweighted average liquidity of the individual equity positions held by the fund."
} 
ownership and illiquid fund ownership and create two binary treatment variables (Treat_LiquidFunds and Treat_IlliquidFunds) based on the median cut-off of liquid fund ownership and illiquid fund ownership, respectively. ${ }^{29}$ It is possible for a firm to be held by both liquid funds and illiquid funds at the same time, so the two separate treatment variables separately capture pressures from the liquid and illiquid funds. Panel A of Table 3 presents the results based on these two treatment variables. The coefficients on Post $\times$ Treat_IlliquidFunds are statistically significant while the coefficients on Post $\times$ Treat_LiquidFunds are not significant. This result further confirms that findings documented in Table 2 are driven by funds' liquidity concerns introduced by the proposed regulation. The finding is also consistent with the prediction that less liquid funds have greater incentives to improve portfolio liquidity.

[Insert Table 3 here]

\subsubsection{Index and Outsourced Funds}

Hypothesis $\mathrm{H} 2 \mathrm{a}$ also predicts that the effect is more pronounced for mutual funds that are non-index funds. I use a variable (index_fund_flag) in the CRSP Mutual Funds database to identify index mutual funds and create two binary treatment variables (Treat_IndexFunds and Treat_NonIndexFunds) based on the median index fund ownership and the median non-index fund ownership, respectively. As above, these variables are not mutually exclusive as the same firm can have above (below) median ownership by both index and non-index funds. Panel B of Table 3 provides evidence in support of H2a. The

\footnotetext{
${ }^{29}$ This approach of decomposing a binary treatment variable into two binary treatment variables in order to capture impacts caused by two different groups of mutual funds is used in prior studies that examine the effect of mutual funds on portfolio firms. For example, investigating the effect of mutual fund portfolio holdings disclosure on innovations, Agarwal et al. (2018) decompose their binary treatment variable into two binary treatment variables based on the median age of mutual fund managers in their Table 7.
} 
effect is more pronounced among non-index funds $(t$-statistic $=4.56)$ than index funds.

Following Chen et al. (2013) and Chuprinin et al. (2015), I identify funds that are outsourced to external asset management companies and funds that are managed in-house. For each firm, I calculate outsourced funds' ownership and in-house funds' ownership prior to the treatment. I create a binary treatment variable (Treat_Outsourced) based on the median outsourced funds' ownership and another binary treatment variable (Treat_InHouse) based on the median in-house funds' ownership. Consistent with Hypothesis H2a, results in Panel B of Table 3 suggest that the effect is concentrated among in-house funds $(t$-statistics $=4.61$ and 3.55) relative to outsourced funds $(t$-statistics $=-0.08$ and 1.35).

\subsubsection{Pre-Treatment Stock Liquidity and Information Asymmetry}

Table 4 examines hypothesis $\mathrm{H} 2 \mathrm{~b}$ regarding the pre-treatment stock liquidity (Panel A) and pre-treatment information asymmetry (Panel B and Panel C) at the firm level. I measure pre-treatment stock liquidity immediately before the event date. I use a firm's market capitalization and analyst coverage immediately before the event date to proxy for information asymmetry. These two information asymmetry proxies are widely used in the literature. For instance, Agarwal et al. (2015) use the same proxies for information asymmetry when studying the effect of fund portfolio holdings disclosure on stock liquidity.

Panel A of Table 4 presents the regression coefficient estimates in the subsamples partitioned based on pre-treatment stock liquidity. In both low liquidity subsamples (Column 1 and Column 3), the coefficients are statistically and economically significant. In contrast, both high liquidity subsamples do not experience a significant stock liquidity improvement. The difference between the two subsamples is statistically significant $(p$ value $<0.001$ in both measures). These results support H2b. For brevity, I only report the 
specification with firm fixed effects and results are similar when I replace firm fixed effects with industry fixed effects.

Panel B and Panel C of Table 4 estimate the coefficients in the subsamples partitioned based on pre-treatment analyst coverage and market capitalization, respectively. Both panels show that the effects are more pronounced in the subsamples with higher information asymmetry before the event (lower analyst coverage or smaller market capitalization). The differences are statistically significant at the $1 \%$ level in all cases. Overall, the results in Table 4 are consistent with hypothesis $\mathrm{H} 2 \mathrm{~b}$.

[Insert Table 4 here]

\subsection{Effect of Mutual Fund Liquidity Management on Corporate Disclosure}

In this section, I evaluate one possible mechanism, corporate disclosure, through which funds' liquidity management affects underlying stocks' liquidity. I examine both voluntary disclosure such as management guidance (Section 4.3.1) and conference calls (Section 4.3.2), and mandatory disclosure such as the readability of quarterly reports (Section 4.3.2). Following prior studies (e.g., Fang et al. 2014; Jayaratne and Strahan 1996), outcome variables (stock liquidity measures) are replaced with mechanism variables (disclosure measures) in Eq. (1).

\subsubsection{Management Earnings Forecasts}

I first estimate a probit regression to investigate whether a firm is more likely to issue quarterly earnings forecasts after the SEC proposal. The dependent variable is Earnings Guidance. The results are presented in Table 5, Column 1. The coefficient on Treat $\times$ Post is 0.24 which is statistically significant at the $1 \%$ level $(t$-statistic=3.03). The marginal effect is $3.26 \%$, which is economically significant considering that the 
unconditional probability of issuing earnings guidance in this sample is $11 \%$. This liquidity management effect is notable because firm disclosure policies tend to be sticky over time (Boone and White 2015; Bushee et al. 2003; Li and Yang 2015). ${ }^{30}$ Results are similar when I use a logit regression. My second test involves estimating an ordered probit model of the precision of management forecasts. Column 2 in Table 5 shows that treatment firms provide more precise forecasts after the liquidity management shock than control firms. Results are similar when I use an ordered logistic regression. These findings are consistent with hypothesis $\mathrm{H} 3$.

\section{[Insert Table 5 here]}

\subsubsection{Conference Calls}

Panel A of Table 6 reports probit regression results of estimating the likelihood of holding conference calls. The coefficient on Treat $\times$ Post is both statistically and economically significant, with treatment firms being $6.88 \%$ more likely to hold conference calls after the proposal announcement relative to control firms. Results are similar if I use a logit regression. Panel B in Table 6 presents results on the readability of conference call presentations and managers' answers during Q\&A sessions (Columns 1 and 2), presentations only (Columns 3 and 4), and managers' answers only (Columns 5 and 6). In all specifications, the coefficients on Treat $\times$ Post are positive (more understandable/readable) and statistically significant at the $1 \%$ level ( $t$-statistics ranging from 3.23 to 10.59). Panel $\mathrm{B}$ indicates that managers in treatment firms provide presentations and answers that are easier for market participants to understand, compared

\footnotetext{
${ }^{30}$ Because of the sticky disclosure policies, Boone and White (2015) include a lagged dependent variable in their 2SLS regressions. I do not include a lagged dependent variable because my estimation is a DID estimator which is not required to control for a lagged outcome variable (Lechner 2011).
} 
to those provided by managers in control firms after the fund liquidity management regulation is proposed. Together, Table 6 provides evidence in support of hypothesis H3.

[Insert Table 6 here]

\subsubsection{Quarterly Reports}

Table 7 examines the effect of fund liquidity management on mandatory disclosure (quarterly reports 10-Qs). In Column 1, the coefficient on Treat $\times$ Post is 0.614 , with a $t$ statistic of 3.98. The readability of quarterly reports is $6.35 \%$ higher among treatment firms than among control firms following the liquidity management proposal. ${ }^{31}$ The result remains statistically and economically significant after controlling for firm fixed effects (Table 7, Column 2). These results are consistent with hypothesis H3.

[Insert Table 7 here]

In summary, the results in Section 4.3 suggest that mutual funds exert pressure on portfolio firms to improve voluntary and mandatory disclosure, which ultimately helps improve stock liquidity. As such, they provide empirical support for Hypothesis 3 that mutual fund liquidity management increases the frequency of voluntary disclosure and improves the quality of voluntary and mandatory disclosures among portfolio firms.

\subsubsection{Validation of A Possible Mechanism}

In this section, I validate the assumption that portfolio firms increase their stock liquidity through improving corporate disclosure. I employ two approaches. In the first approach, I examine whether stock liquidity improvement is driven by disclosure improvement around the SEC proposal. To identify disclosure improvement, I use five

\footnotetext{
${ }^{31} 0.614$ (coefficient) $/|-9.666|($ mean $)=6.35 \%$
} 
individual measures of disclosure improvement (Panel A of Table 8) and two composite measures of disclosure improvement (Panel B of Table 8). In Panel A of Table 8, for each disclosure dimension, I use an indicator variable (Improved_Disclosure) that equals one if a specific dimension of a treatment firm's disclosure (earnings guidance likelihood, guidance precision, conference call likelihood, call readability, or quarterly report readability) improved during the post-treatment period relative to the pre-treatment period, and zero otherwise. I replace Treat in Equation (1) with Improved_Disclosure and estimate the modified regressions. ${ }^{32}$ I do not include Post (Improved_Disclosure), because it is absorbed by year-quarter (firm) fixed effects. Panel A of Table 8 presents the results. The coefficients on Improved_Disclosure $\times$ Post are significantly positive in all columns, indicating that the liquidity improvement is at least partially driven by the improvement in corporate disclosure.

In Panel B of Table 8, I construct two composite measures of disclosure improvement. Improved_Disclosurel is an indicator variable that equals one if at least one dimension of a treatment firm's disclosure is improved in the post-treatment period relative to the pre-treatment period, and zero otherwise. Improved_Disclosure2 is an indicator variable that equals one if at least one dimension of a treatment firm's disclosure is improved and all other dimensions of disclosure do not become worse in the post-treatment period relative to the pre-treatment period, and zero otherwise. I continue to find similar results using these two composite measures of disclosure improvement. In summary, these results show that portfolio firms that improve disclosure after the SEC proposal experience

\footnotetext{
${ }^{32}$ Replacing a treatment variable with a non-treatment variable in a DID setting is often used for supplementary analyses in the literature. For example, Agarwal et al. (2018) replace their treatment variable with performance measures (see page 1995 and Table IA13).
} 
an improvement in stock liquidity following the SEC proposal, suggesting that disclosure is one of possible mechanisms through which liquidity management at the fund level affects stock liquidity at the firm level.

[Insert Table 8 here]

I also employ another approach to provide further evidence that disclosure is a possible mechanism through which mutual funds' liquidity management improves portfolio firms' stock liquidity. Prior studies show that disclosure has proprietary costs (e.g., Li et al. 2018). Therefore, firms incur proprietary costs when using disclosure to increase stock liquidity. If disclosure is one of the mechanisms emphasized by mutual funds to improve stock liquidity of portfolio firms, the effect of mutual fund liquidity management on stock liquidity is expected to be more pronounced for firms with low proprietary costs of disclosure than those with high proprietary costs of disclosure, because proprietary costs of disclosure may outweigh the benefits of increased stock liquidity for firms facing high proprietary costs.

To test this prediction, I examine how my difference-in-differences estimates from Table 2 vary across firms with higher versus lower proprietary costs of disclosure. I follow prior literature and use competition to proxy for proprietary costs of disclosure as proprietary costs are not directly observable. Specifically, I use a firm-specific competition measure developed by Li et al. (2013) to proxy for a firm's proprietary costs of disclosure (e.g., Choi et al. 2019). I measure competition immediately before the SEC proposal and use the sample median to split the sample into high and low proprietary cost subsamples. Then I estimate Equation (1) separately for the two subsamples and compare the coefficients on Treat $\times$ Post between the two subsamples. I expect the coefficients on 
Treat $\times$ Post in the low proprietary cost subsample to be more pronounced than the high proprietary cost subsample if disclosure is one of the mechanisms used to improve stock liquidity of portfolio firms.

Results reported in Table 9 are consistent with this prediction. The coefficients are statistically significant at the $1 \%$ level in the low proprietary cost group while the coefficients are insignificant in the high proprietary cost group. The differences in coefficients between the two groups are also statistically significant at the $1 \%$ level. These results provide further evidence that disclosure is a possible mechanism through which mutual fund liquidity management affects stock liquidity of portfolio firms. While this paper does not claim that disclosure is the only channel, the insignificant results in the high proprietary cost group indicate that when disclosure is costly, there are not many alternatives that firms can use to improve stock liquidity.

[Insert Table 9 here]

Together, the results of Tables 8 and 9 suggest that improving corporate disclosure is one of channels through which liquidity management by mutual funds increases their portfolio firms' stock liquidity.

\section{ADDITIONAL ANALYSES}

\subsection{Continuous Treatment Variables}

As mutual fund ownership is continuous, I employ an alternative difference-indifferences research design where the treatment variable is continuous (Agarwal et al. 2015). Table 10 presents stock liquidity and disclosure results. The interpretation of DID with a binary treatment variable applies to DID with a continuous treatment variable (Angrist and Pischke 2009). All coefficients on the interaction term between the continuous 
treatment variable and Post are positive and statistically significant at the $1 \%$ level, suggesting that fund liquidity management can improve stock liquidity and disclosure.

[Insert Table 10 here]

\subsection{Robustness Checks}

\subsubsection{Alternative Stock Liquidity Measures}

In untabulated analyses, I examine the robustness of my results using six alternative stock liquidity measures. I first use Amihud and Spread without the log transformation. I continue to find robust results with these two liquidity measures ( $t$-statistics ranging from 4.32 to 6.78). Next, I use Turnover, Dollar Volume, and their log transformations to measure stock liquidity, because stock turnover and dollar amounts of trading volume are often used as alternative liquidity measures in prior studies (e.g., Boone and White 2015). In addition, trading volume is one of the liquidity measures that the SEC liquidity management regulation requires fund managers to consider. My results remain robust to using these alternative measures ( $t$-statistics ranging from 4.39 to 16.12 ). Furthermore, I apply these alternative stock liquidity measures to the specifications using the continuous treatment variable and continue to find robust results ( $t$-statistics ranging from 4.76 to 18.61).

\subsubsection{Alternative Binary Treatment Variable}

While using a binary treatment variable based on the median fund ownership is widely used in prior literature (e.g., Agarwal et al. 2018), I perform a robustness test to confirm that my results are robust to using control firms without receiving any pressure from mutual funds. Specifically, I define an alternative binary treatment variable that equals one if the pre-treatment fund ownership is greater than zero. In untabulated results, 
I continue to find the coefficients on Treat $\times$ Post to be positive and statistically significant at the $1 \%$ level in all specifications using both the main and alternative liquidity measures.

\subsection{Placebo Tests}

Following prior studies (e.g., Li and Zhang 2015) using DID, I perform a set of placebo tests based on a placebo event date three years before the actual event date. I choose September 22, 2012 as a placebo event date because it is the date closest to the real event date under the condition that the placebo sample period (from September 22, 2009 to September 21, 2015) does not cover the actual event date, avoiding being affected by the actual SEC proposal. Table 11 presents the regression results. I do not find the coefficients on Treat $\times$ Post_Placebo to be significant in all specifications. These insignificant results further confirm that my results are not driven by any specific time trends (Lechner 2011).

\section{[Insert Table 11 here]}

I also perform another set of placebo tests based on the ownership held by nonmutual fund institutions that are not affected by the SEC proposal and thus are not expected to demand more stock liquidity of portfolio firms following the SEC proposal. To measure the ownership of unaffected institutional investors, I first calculate ownership held by all institutional investors, including mutual funds and non-mutual fund institutions. Then I subtract mutual fund ownership from the total institutional ownership to obtain unaffected ownership. I create two treatment variables Treat_IO and Treat_Unaffected. Treat_IO is an indicator variable that equals one if total institutional ownership (including mutual fund ownership) in the quarter immediately before September 22, 2015 is more than the median total institutional ownership and zero otherwise. Treat_Unaffected is an indicator variable 
that equals one if unaffected ownership in the quarter immediately before September 22, 2015 is more than the median unaffected ownership and zero otherwise, where unaffected ownership equals total institutional ownership minus mutual fund ownership. Treat_Unaffected is a placebo treatment variable.

I replace Treat with Treat_IO in Equation (1) and report the results in Columns 1 and 2 of Table 12. The coefficients on Treat_IO $\times$ Post are statistically significant at the $1 \%$ level with lower magnitudes compared to the coefficients reported in Table 2. The coefficients are significant because the total institutional ownership contains mutual fund ownership, and the magnitudes are reduced because the total institutional ownership contains ownership held by non-mutual fund institutions that are not affected by the SEC proposal. To differentiate mutual fund ownership and unaffected ownership, I add Treat_Unaffected and Treat_Unaffected $\times$ Post in Equation (1). I expect the coefficients on Treat $\times$ Post to be significantly positive and the coefficients on Treat_Unaffected $\times$ Post to be insignificant. Columns 3 and 4 in Table 12 report the results. Consistent with my prediction, the coefficients on Treat $\times$ Post remain economically and statistically significant, while the coefficients on Treat_Unaffected $\times$ Post are not statistically significant and the magnitudes are very small. These insignificant results provide further evidence that the improvement in stock liquidity is induced by mutual funds for the purpose of liquidity management.

\section{[Insert Table 12 here]}

\subsection{Alternative Explanation}

An alternative explanation is that firms may voluntarily improve their stock liquidity to keep their current mutual fund owners and attract new mutual fund owners after 
the SEC proposal, as firms may expect that mutual funds will prefer firms with high stock liquidity due to the liquidity management shock. This alternative explanation may not hold for two reasons. First, if this is the case, we would expect firms with low mutual fund ownership to have a greater increase in stock liquidity because these firms have stronger incentives to attract mutual funds. However, I find that portfolio firms with high mutual fund ownership have greater improvements in stock liquidity than portfolio firms with low mutual fund ownership. Second, if the change in liquidity is purely driven by firms' incentives to keep or attract mutual funds, we would not expect that mutual funds' incentives and ability will influence the relation between the shock and liquidity improvements, because under this alternative explanation mutual funds do not influence firms to improve stock liquidity. However, my results show that the improvement in stock liquidity is stronger when mutual funds have stronger incentives and higher ability to influence portfolio firms' stock liquidity.

It is possible that this alternative explanation and my explanation are not mutually exclusive, and my explanation dominates the relation between the shock and liquidity improvements. Moreover, firms' voluntarily improving stock liquidity is due to the fact that mutual funds have stock liquidity preference. Thus, this voluntary behavior by firms is induced by mutual fund liquidity management. In other words, mutual fund liquidity management is the ultimate reason for portfolio firms to improve stock liquidity.

\subsection{Changes in Mutual Fund Ownership}

Mutual funds may sell illiquid stocks and buy liquid stocks after the SEC proposal to improve portfolio liquidity. This is one of tools mutual funds can use to manage portfolio liquidity. There are two consequences related to my study when mutual funds use this tool 
to manage their portfolio liquidity. First, the liquidity of illiquid stocks will become even worse because the demand of illiquid stocks is reduced. Second, the liquidity of liquid stocks will become better because the demand of liquid stocks is increased. This may create bias against me to find the results.

To further mitigate this concern, I control for mutual fund ownership as a robustness check. The results are reported in Table 13. The coefficients on Treat $\times$ Post remain statistically and economically significant after controlling for concurrent mutual fund ownership. The results are similar if I control for lagged mutual fund ownership. In summary, my results are robust to mutual funds' rebalancing behavior.

[Insert Table 13 here]

\section{CONCLUSION}

In this paper, I use a quasi-natural experiment created by the SEC mutual fund liquidity management proposal to examine a new and unresolved question of whether mutual funds, for the purpose of liquidity management, influence their portfolio firms' stock liquidity and disclosure activities. My results provide causal evidence that mutual fund liquidity management improves liquidity of underlying stocks. Further analyses find that the stock liquidity improvement is more pronounced among funds that have stronger incentives to increase liquidity and more resources to influence portfolio firms. My findings are stronger among firms having lower pre-treatment stock liquidity and higher pre-treatment information asymmetry. I also document that mutual funds improve stock liquidity of portfolio firms through enhancing these firms' voluntary and mandatory disclosures.

This paper is the first to evaluate the causal effects of the mutual fund liquidity 
management regulation on public firms. The results in this paper should be of interest to regulators, researchers, and practitioners. For regulators, the results inform them of the consequences of mutual fund liquidity management regulations that they have adopted or consider adopting. For researchers in accounting and finance, both stock liquidity and disclosure are central to the capital market research and mutual fund liquidity management becomes an increasingly important research topic. For practitioners, my paper suggests that mutual fund liquidity management can play an important role in portfolio management. Requesting portfolio firms to improve disclosure and liquidity is an effective way of fund liquidity management. While I show fund liquidity management can benefit firms in terms of improving their stock liquidity, my study does not shed light on the costs of implementing liquidity management and increasing firm disclosure. 


\section{REFERENCES}

Agarwal, V., K. A. Mullally, Y. Tang, and B. Yang. 2015. Mandatory Portfolio Disclosure, Stock Liquidity, and Mutual Fund Performance. The Journal of Finance 70 (6): 2733-2776.

Agarwal, V., R. Vashishtha, and M. Venkatachalam. 2018. Mutual Fund Transparency and Corporate Myopia. The Review of Financial Studies 31 (5): 1966-2003.

Agarwal, V., and H. Zhao. 2019. Interfund Lending in Mutual Fund Families: Role in Liquidity Management. The Review of Financial Studies 32 (10): 4079-4115.

Ajinkya, B., S. Bhojraj, and P. Sengupta. 2005. The Association between Outside Directors, Institutional Investors and the Properties of Management Earnings Forecasts. Journal of Accounting Research 43 (3): 343-376.

Amihud, Y. 2002. Illiquidity and Stock Returns: Cross-Section and Time-Series Effects. Journal of Financial Markets 5 (1): 31-56.

Angrist, J. D., and J.-S. Pischke. 2009. Mostly Harmless Econometrics: An Empiricist's Companion. Princeton University Press.

Appel, I. R., T. A. Gormley, and D. B. Keim. 2016. Passive Investors, Not Passive Owners. Journal of Financial Economics 121 (1): 111-141.

Armstrong, C. S., J. E. Core, and W. R. Guay. 2014. Do Independent Directors Cause Improvements in Firm Transparency? Journal of Financial Economics 113 (3): 383-403.

Balakrishnan, K., M. B. Billings, B. Kelly, and A. Ljungqvist. 2014. Shaping Liquidity: On the Causal Effects of Voluntary Disclosure. The Journal of Finance 69 (5): 2237-2278.

Bamber, L. S., J. (Xuefeng) Jiang, and I. Y. Wang. 2010. What's My Style? The Influence of Top Managers on Voluntary Corporate Financial Disclosure. The Accounting Review 85 (4): $1131-1162$.

Boone, A. L., and J. T. White. 2015. The Effect of Institutional Ownership on Firm Transparency and Information Production. Journal of Financial Economics 117 (3): 508-533.

Bourveau, T., Y. Lou, and R. Wang. 2018. Shareholder Litigation and Corporate Disclosure: Evidence from Derivative Lawsuits. Journal of Accounting Research 56 (3): 797-842.

Bradshaw, M. T., S. A. Richardson, and R. G. Sloan. 2006. The Relation between Corporate Financing Activities, Analysts' Forecasts and Stock Returns. Journal of Accounting and Economics 42 (1): 53-85.

Brown, S., S. A. Hillegeist, and K. Lo. 2004. Conference Calls and Information Asymmetry. Journal of Accounting and Economics 37 (3): 343-366.

Brunnermeier, M. K. 2009. Deciphering the Liquidity and Credit Crunch 2007-2008. Journal of Economic Perspectives 23 (1): 77-100. 
Bushee, B. J., D. A. Matsumoto, and G. S. Miller. 2003. Open versus Closed Conference Calls: The Determinants and Effects of Broadening Access to Disclosure. Journal of Accounting and Economics 34 (1): 149-180.

Bushee, B. J., and C. F. Noe. 2000. Corporate Disclosure Practices, Institutional Investors, and Stock Return Volatility. Journal of Accounting Research 38: 171-202.

Bushman, R. M., and R. J. Indjejikian. 1995. Voluntary Disclosures and the Trading Behavior of Corporate Insiders. Journal of Accounting Research: 293-316.

Cao, C., M. Gustafson, and R. Velthuis. 2018. Index Membership and Small Firm Financing. Management Science.

Cassell, C. A., S. X. Huang, and J. M. Sanchez. 2013. Forecasting without Consequence? Evidence on the Properties of Retiring CEOs' Forecasts of Future Earnings. The Accounting Review 88 (6): 1909-1937.

Chen, J., H. Hong, W. Jiang, and J. D. Kubik. 2013. Outsourcing Mutual Fund Management: Firm Boundaries, Incentives, and Performance. The Journal of Finance 68 (2): 523-558.

Chen, Q., and R. Vashishtha. 2017. The Effects of Bank Mergers on Corporate Information Disclosure. Journal of Accounting and Economics 64 (1): 56-77.

Chen, S., Y. Huang, N. Li, and T. Shevlin. 2019. How Does Quasi-Indexer Ownership Affect Corporate Tax Planning? Journal of Accounting and Economics 67 (2): 278-296.

Chernenko, S., and A. Sunderam. 2016. Liquidity Transformation in Asset Management: Evidence from the Cash Holdings of Mutual Funds. Working paper, National Bureau of Economic Research.

Choi, L., L. Faurel, and S. A. Hillegeist. 2019. Do Proprietary Costs Deter Insider Trading? Working paper, City University of Hong Kong.

Chuprinin, O., M. Massa, and D. Schumacher. 2015. Outsourcing in the International Mutual Fund Industry: An Equilibrium View. The Journal of Finance 70 (5): 2275-2308.

Cohn, J. B., S. L. Gillan, and J. C. Hartzell. 2016. On Enhancing Shareholder Control: A (Dodd-) Frank Assessment of Proxy Access. The Journal of Finance 71 (4): 1623-1668.

Coller, M., and T. L. Yohn. 1997. Management Forecasts and Information Asymmetry: An Examination of Bid-Ask Spreads. Journal of Accounting Research 35 (2): 181-191.

Correia, S. 2015. Singletons, Cluster-Robust Standard Errors and Fixed Effects: A Bad Mix. Working paper, Duke University.

Coval, J., and E. Stafford. 2007. Asset Fire Sales (and Purchases) in Equity Markets. Journal of Financial Economics 86 (2): 479-512. 
Crane, A. D., S. Michenaud, and J. P. Weston. 2016. The Effect of Institutional Ownership on Payout Policy: Evidence from Index Thresholds. The Review of Financial Studies 29 (6): 1377-1408.

De Simone, L., J. D. Piotroski, and R. E. Tomy. 2019. Repatriation Taxes and Foreign Cash Holdings: The Impact of Anticipated Tax Reform. The Review of Financial Studies 32 (8): 3105-3143.

deHaan, E., J. Madsen, and J. D. Piotroski. 2017. Do Weather-Induced Moods Affect the Processing of Earnings News? Journal of Accounting Research 55 (3): 509-550.

Diamond, D. W. 1985. Optimal Release of Information by Firms. The Journal of Finance 40 (4): 1071-1094.

Diamond, D. W., and R. E. Verrecchia. 1991. Disclosure, Liquidity, and the Cost of Capital. The Journal of Finance 46 (4): 1325-1359.

Duan, Y., and Y. Jiao. 2016. The Role of Mutual Funds in Corporate Governance: Evidence from Mutual Funds' Proxy Voting and Trading Behavior. Journal of Financial and Quantitative Analysis 51 (2): 489-513.

Edmans, A., V. W. Fang, and E. Zur. 2013. The Effect of Liquidity on Governance. The Review of Financial Studies 26 (6): 1443-1482.

Fang, V. W., X. Tian, and S. Tice. 2014. Does Stock Liquidity Enhance or Impede Firm Innovation? The Journal of Finance 69 (5): 2085-2125.

Graham, J. R., C. R. Harvey, and S. Rajgopal. 2005. The Economic Implications of Corporate Financial Reporting. Journal of Accounting and Economics 40 (1): 3-73.

Greene, W. H. 2012. Econometric Analysis. Pearson.

Hanouna, P., J. Novak, T. Riley, and C. Stahel. 2015. Liquidity and Flows of U.S. Mutual Funds. Working paper, U.S. Securities and Exchange Commission.

Jayaratne, J. and P. E. Strahan. 1996. The Finance-Growth Nexus: Evidence from Bank Branch Deregulation. The Quarterly Journal of Economics 111(3): 639-670.

Kang, J.-K., J. Luo, and H. S. Na. 2018. Are Institutional Investors with Multiple Blockholdings Effective Monitors? Journal of Financial Economics 128 (3): 576-602.

Khan, M., S. Srinivasan, and L. Tan. 2017. Institutional Ownership and Corporate Tax Avoidance: New Evidence. The Accounting Review 92 (2): 101-122.

Kim, I., and D. J. Skinner. 2012. Measuring Securities Litigation Risk. Journal of Accounting and Economics 53 (1): 290-310.

Lancaster, T. 2000. The Incidental Parameter Problem Since 1948. Journal of Econometrics 95 (2): 391-413. 
Lechner, M. 2011. The Estimation of Causal Effects by Difference-in-Difference Methods. Foundations and Trends in Econometrics 4 (3): 165-224.

Lee, Y. J. 2012. The Effect of Quarterly Report Readability on Information Efficiency of Stock Prices. Contemporary Accounting Research 29 (4): 1137-1170.

Lemmon, M., and M. R. Roberts. 2010. The Response of Corporate Financing and Investment to Changes in the Supply of Credit. Journal of Financial and Quantitative Analysis 45 (3): $555-587$.

Li, F., R. Lundholm, and M. Minnis. 2013. A Measure of Competition Based on 10-K Filings. Journal of Accounting Research 51 (2): 399-436.

Li, X., and H. I. Yang. 2015. Mandatory Financial Reporting and Voluntary Disclosure: The Effect of Mandatory IFRS Adoption on Management Forecasts. The Accounting Review 91 (3): 933-953.

Li, Y., and L. Zhang. 2015. Short Selling Pressure, Stock Price Behavior, and Management Forecast Precision: Evidence from a Natural Experiment. Journal of Accounting Research 53 (1): 79-117.

Li, Y., Y. Lin, and L. Zhang. 2018. Trade Secrets Law and Corporate Disclosure: Causal Evidence on the Proprietary Cost Hypothesis. Journal of Accounting Research 56(1): 265-308.

Lin, C., M. S. Officer, T. Schmid, and H. Zou. 2019. Is Skin in the Game a Game Changer? Evidence from Mandatory Changes of D\&O Insurance Policies. Journal of Accounting and Economics 68 (1): 1-22.

Loughran, T., and B. Mcdonald. 2014. Measuring Readability in Financial Disclosures. The Journal of Finance 69 (4): 1643-1671.

Luong, H., F. Moshirian, L. Nguyen, X. Tian, and B. Zhang. 2017. How Do Foreign Institutional Investors Enhance Firm Innovation? Journal of Financial and Quantitative Analysis 52 (4): 1449-1490.

McCahery, J. A., Z. Sautner, and L. T. Starks. 2016. Behind the Scenes: The Corporate Governance Preferences of Institutional Investors. The Journal of Finance 71 (6): 2905-2932.

Neyman, J., and E. L. Scott. 1948. Consistent Estimates Based on Partially Consistent Observations. Econometrica 16 (1): 1-32.

Ren, H. 2019. Mutual Fund Redemptions in Kind. Dissertation, Georgia State University.

Rogers, J. L., and A. Van Buskirk. 2009. Shareholder Litigation and Changes in Disclosure Behavior. Journal of Accounting and Economics 47 (1): 136-156. 
Schmidt, C., and R. Fahlenbrach. 2017. Do Exogenous Changes in Passive Institutional Ownership Affect Corporate Governance and Firm Value? Journal of Financial Economics 124 (2): 285-306.

Schoenfeld, J. 2017. The Effect of Voluntary Disclosure on Stock Liquidity: New Evidence from Index Funds. Journal of Accounting and Economics 63 (1): 51-74.

SEC. 2015. Open-End Fund Liquidity Risk Management Programs. Proposed rule. U.S. Securities and Exchange Commission.

Simutin, M. 2014. Cash Holdings and Mutual Fund Performance. Review of Finance 18 (4): 14251464.

Vayanos, D., and J. Wang. 2013. Market Liquidity-Theory and Empirical Evidence. In Handbook of the Economics of Finance, edited by G. M. Constantinides, M. Harris, and R. M. Stulz, 2:1289-1361. Elsevier.

Wermers, R. 2000. Mutual Fund Performance: An Empirical Decomposition into Stock-Picking Talent, Style, Transactions Costs, and Expenses. The Journal of Finance 55 (4): 16551695.

Witmer, J. 2019. Strategic Complementarities and Money Market Fund Liquidity Management. Journal of Financial Intermediation 38: 58-68.

Yan, X. (Sterling). 2008. Liquidity, Investment Style, and the Relation between Fund Size and Fund Performance. Journal of Financial and Quantitative Analysis 43 (3): 741-767.

Zeng, Y. 2017. A Dynamic Theory of Mutual Fund Runs and Liquidity Management. Working paper, University of Washington. 


\section{APPENDIX A}

\section{DETAILS OF THE SEC PROPOSAL}

\section{Panel A. Timeline of Rules}

09/22/2015 The SEC proposed mutual fund liquidity management rules.

10/13/2016 The SEC adopted proposed rules with minor changes.

01/17/2017 The mutual fund liquidity management rules became effective.

12/01/2018 Mutual funds with net assets of \$1 billion or more began compliance.

06/01/2019 Mutual funds with net assets of less than $\$ 1$ billion began compliance.

\section{Panel B. Regulatory Requirements}

1. Each mutual fund is required to establish a liquidity risk management program.

2. Each mutual fund is required to classify each of its portfolio assets into one of six liquidity categories based on the number of days within which the asset will be convertible to cash at a price that does not materially affect the value of that asset immediately prior to sale. The six liquidity categories include (1) 1 business day; (2) 2-3 business days; (3) 4-7 calendar days; (4) 8-15 calendar days; (5) 16-30 calendar days; (6) more than 30 calendar days.

In addition, each mutual fund is required to consider the following factors when classifying the liquidity of each stock position (this appendix only covers factors related to stocks):

(1) Bid-ask spreads;

(2) Daily trading volume and frequency of trades or quotes;

(3) The number, diversity, and quality of market participants;

(4) Volatility of trading prices;

(5) The ratio of the fund's holding size of the stock to the daily trading volume of the stock and the ratio of the fund's holding shares of the stock to the shares outstanding of the stock; (6) Relationship of the stock to another asset in the fund's portfolio.

3. Each mutual fund is required to disclose information regarding the liquidity of the fund's holdings and its liquidity risk management program.

4. Each mutual fund is required to determine the fund's minimum percentage of the fund's net assets to be invested in three-day liquid assets with a written record of how the minimum is determined, where three-day liquid asset is defined as any cash or asset held by a fund that can be convertible into cash within three business days at a price that does not materially affect the value of that asset immediately prior to sale. A fund would be prohibited from acquiring any less liquid asset if, immediately after the acquisition, the fund would have invested less than this minimum.

5. A fund would be prohibited from acquiring any $15 \%$ standard asset if, immediately after the acquisition, the fund would have invested more than $15 \%$ of its net assets in $15 \%$ standard assets, where a $15 \%$ standard asset is defined as any asset that may not be sold or disposed of within seven calendar days at approximately the value ascribed to it by the fund. 


\section{APPENDIX B}

\section{VARIABLE DEFINITIONS}

\section{Stock Liquidity Measures}

Amihud is the quarterly average of a stock's daily stock liquidity developed in Amihud (2002). It is constructed as follows. Following Amihud (2002), I use daily CRSP data to calculate the daily stock liquidity as $(-1) \times \frac{\text { Return } \times 10^{6}}{\text { Price } \times \text { Volume }}$ for each day in a fiscal quarter, where Return is the daily stock return, Price is the daily closing price, and Volume is the daily total number of shares sold. I then average the daily stock liquidity over the fiscal quarter. (Data source: CRSP)

$\log$ Amihud is the natural logarithm of one plus quarterly Amihud for each fiscal quarter. Spread is the quarterly average of a stock's daily bid-ask spread. I use daily CRSP data to calculate the daily bid-ask spread as $(-1) \times \frac{100 \times(A s k-B i d)}{(A s k+B i d) / 2}$, where Ask is the daily closing ask price, and Bid is the daily closing bid price. I then average the daily bid-ask spread over the fiscal quarter. (Data source: CRSP)

Log Spread is the natural logarithm of one plus quarterly Spread for each fiscal quarter.

Turnover is the quarterly average of a stock's daily turnover. I use daily CRSP data to calculate the daily turnover as $\frac{\text { Volume }}{\text { Shares }}$, where Volume is the daily total number of shares sold, and Shares is the daily total number of shares outstanding. I then average the daily turnover over the fiscal quarter. (Data source: CRSP)

Log Turnover is the natural logarithm of one plus quarterly Turnover for each fiscal quarter.

Dollar Volume is the quarterly average of a stock's daily dollar volume. I use daily CRSP data to calculate the daily dollar volume as Volume $\times$ Price, where Volume is the daily total number of shares sold, and Price is the daily closing price. I then average the daily dollar volume over the fiscal quarter. (Data source: CRSP)

Log Dollar Volume is the natural logarithm of one plus quarterly Dollar Volume for each fiscal quarter.

2. Control Variables for Stock Liquidity (following Balakrishnan et al. (Journal of Finance, 2014, p. 2249-2250))

Size is the natural logarithm of market capitalization at the end of the fiscal quarter. (Data source: Compustat)

Stock Return Volatility is the standard deviation of daily stock returns in the fiscal quarter. (Data source: CRSP)

Analyst Coverage is the number of analysts covering the firm in the fiscal quarter. (Data source: IBES)

3. Groups of Mutual Funds (identified immediately before September 22, 2015)

IlliquidFunds is a group of mutual funds whose portfolio liquidity is below the median portfolio liquidity. Portfolio liquidity is measured as the value-weighted liquidity of stocks in the portfolio, i.e., $\sum W_{\text {eight }} \times$ Stock_Liquidity $_{i}$, where $W_{\text {eight }}$ is the portfolio weight on stock $i$, and Stock_Liquidity $i$ is Log Amihud of stock $i$. This portfolio liquidity 
measure is the same as the one used by the SEC in the proposal. (Data source: CRSP and Thomson Reuters)

LiquidFunds is a group of mutual funds whose portfolio liquidity is above the median portfolio liquidity. (Data source: CRSP and Thomson Reuters)

Outsourced is a group of mutual funds that are outsourced. Following Chen et al. (2013) and Chuprinin et al. (2015), I identify a mutual fund as an outsourced mutual fund if the name of this mutual fund's advisor is different from the name of the mutual fund family complex and the advisor is not affiliated. (Data source: hand-collection)

In-House is a group of mutual funds that are managed within the mutual fund family complex. (Data source: hand-collection)

IndexFunds is a group of index mutual funds. I use a variable (index_fund_flag) in the CRSP Mutual Funds database to identify index mutual funds. A mutual fund is identified as an index fund if index_fund_flag is equal to B, D, or E. (Data source: CRSP)

NonIndexFunds is a group of mutual funds that are not index funds. (Data source: CRSP)

\section{Pre-Treatment Stock Liquidity}

Pre-Treatment Log Amihud is the natural logarithm of one plus quarterly Amihud for the fiscal quarter immediately before September 22, 2015. (Data source: CRSP)

Pre-Treatment Log Spread is the natural logarithm of one plus quarterly Spread for the fiscal quarter immediately before September 22, 2015. (Data source: CRSP)

\section{Pre-Treatment Information Asymmetry}

Analyst Coverage is the number of analysts cover the firm in the fiscal quarter immediately before September 22, 2015. (Data source: IBES)

Market Capitalization is the natural logarithm of market capitalization at the end of the fiscal quarter immediately before September 22, 2015. (Data source: Compustat).

\section{Information Disclosure Variables}

Earnings Guidance is an indicator variable that equals one if the firm issues at least one management quarterly earnings forecast in the fiscal quarter and zero otherwise. (Data source: IBES)

Guidance Precision measures the precision of management quarterly earnings forecasts issued in the fiscal quarter. It equals 4 if the forecast is a point forecast, 3 if the forecast is a range forecast, 2 if the forecast is an open-ended forecast, 1 if the forecast is a qualitative forecast, and 0 if there is no forecast in the fiscal quarter. (Data source: IBES)

Conference Call is an indicator variable that equals one if the firm holds at least one conference call in the fiscal quarter and zero otherwise. (Data source: hand-collection)

Call Readability is the Gunning Fog index of the conference call transcripts, multiplied by (-1). (Data source: hand-collection)

Gross File Size is the text document file size (in megabytes) of the firm's 10-Q filed in the fiscal quarter. (Data source: Professor Bill McDonald)

Quarterly Report Readability is a measure of quarterly report readability developed in Loughran and Mcdonald (2014) and is measured as Gross File Size multiplied by (-1).

Improved_Disclosure is an indicator variable that equals one if a specific dimension of a treatment firm's disclosure (earnings guidance likelihood, guidance precision, conference 
call likelihood, call readability, or quarterly report readability) is improved in the posttreatment period relative to the pre-treatment period, and zero otherwise.

Improved_Disclosure1 is an indicator variable that equals one if at least one dimension of a treatment firm's disclosure (earnings guidance likelihood, guidance precision, conference call likelihood, call readability, or quarterly report readability) is improved in the post-treatment period relative to the pre-treatment period, and zero otherwise.

Improved_Disclosure2 is an indicator variable that equals one if at least one dimension of a treatment firm's disclosure (earnings guidance likelihood, guidance precision, conference call likelihood, call readability, or quarterly report readability) is improved and all other dimensions of disclosure do not become worse in the post-treatment period relative to the pre-treatment period, and zero otherwise.

\section{Control Variables for Information Disclosure}

Stock Return is the cumulative stock return in the fiscal quarter. (Data source: CRSP)

Stock Return Volatility is the standard deviation of daily stock returns in the fiscal quarter. (Data source: CRSP)

$\boldsymbol{B} / \boldsymbol{M}$ is the book value of equity divided by the market value of equity at the beginning of the fiscal quarter. (Data source: Compustat)

Size is the natural logarithm of market capitalization at the end of the fiscal quarter. (Data source: Compustat)

Earnings Volatility is the standard deviation of quarterly net income in the past 12 quarters with a minimum of three quarters of data. (Data source: Compustat)

$\boldsymbol{R} \& \boldsymbol{D}$ is an indicator variable that equals one if research and development expense in the fiscal quarter is more than zero and zero otherwise. (Data source: Compustat)

Analyst Coverage is the number of analysts covering the firm in the fiscal quarter. (Data source: IBES).

News is an indicator variable that equals one if the EPS of current fiscal quarter $t$ is greater than or equal to the EPS of fiscal quarter $t-4$ and zero otherwise. (Data source: Compustat)

Loss is an indicator variable that equals one if the EPS in the fiscal quarter is less than zero and zero otherwise. (Data source: Compustat)

Analyst Dispersion is standard deviation of analysts' earnings forecasts divided by the stock price at the beginning of the fiscal quarter. (Data source: IBES)

External Financing is an indicator variable that equals one if the fiscal year's external financing is greater than zero and zero otherwise, where the external financing is measured following Bradshaw et al. (2006). (Data source: Compustat)

Litigation is firm-year ex ante litigation risk, estimated using the coefficient estimates from model (3) in Kim and Skinner (2012). (Data source: Compustat)

Competition is a firm-year measure of competition developed in Li et al. (2013) and is calculated as $1000 \times \frac{\text { number of competition related words }}{\text { total number of words }}$ in the current year's $10-\mathrm{K}$ filing, where competition related words include competition, competitor, competitive, compete, competing and those words with an "s" appended. Following Li et al. (2013), I don't count cases where "not," "less," "few," or "limited" precedes the competition related word by three or fewer words. (Data source: EDGAR) 


\section{Treatment Related Variables}

Post is an indicator variable that equals one if the observation is in the post-treatment period (i.e., from 9/22/2015 to 9/22/2018) and zero otherwise.

Treat is an indicator variable that equals one if mutual fund ownership in the quarter immediately before September 22, 2015 is more than the median mutual fund ownership and zero otherwise.

Pre1 is an indicator variable that equals one if the observation is in the first year prior to the SEC proposal date (i.e., from 9/22/2014 to 9/22/2015), and zero otherwise.

Pre 2 is an indicator variable that equals one if the observation is in the second year prior to the SEC proposal date (i.e., from 9/22/2013 to 9/22/2014), and zero otherwise.

Treat_IlliquidFunds is an indicator variable that equals one if ownership held by IlliquidFunds is more than the median ownership held by IlliquidFunds and zero otherwise.

Treat_LiquidFunds is an indicator variable that equals one if ownership held by LiquidFunds is more than the median ownership held by LiquidFunds and zero otherwise.

Treat_Outsourced is an indicator variable that equals one if ownership held by Outsourced is more than the median ownership held by Outsourced and zero otherwise.

Treat_In-House is an indicator variable that equals one if ownership held by In-House is more than the median ownership held by In-House and zero otherwise.

Treat_IndexFunds is an indicator variable that equals one if ownership held by IndexFunds is more than the median ownership held by IndexFunds and zero otherwise.

Treat_NonIndexFunds is an indicator variable that equals one if ownership held by NonIndexFunds is more than the median ownership held by NonIndexFunds and zero otherwise.

TreatOwn is the mutual fund ownership in the quarter immediately before September 22, 2015.

Post_Placebo is an indicator variable that equals one if the observation is in the placebo post-treatment period (i.e., from 9/22/2012 to 9/21/2015), and zero otherwise.

Treat_IO is an indicator variable that equals one if total institutional ownership (including mutual fund ownership) in the quarter immediately before September 22, 2015 is more than the median total institutional ownership and zero otherwise.

Treat_Unaffected is an indicator variable that equals one if unaffected ownership in the quarter immediately before September 22, 2015 is more than the median unaffected ownership and zero otherwise, where unaffected ownership equals total institutional ownership minus mutual fund ownership. 
Table 1

Descriptive Statistics

\begin{tabular}{|c|c|c|c|c|c|c|}
\hline Variables & $\mathrm{N}$ & Mean & SD & P25 & Median & P75 \\
\hline \multicolumn{7}{|c|}{ Main Variables in Stock Liquidity Analyses: } \\
\hline Treat & 99,772 & 0.504 & 0.500 & 0.000 & 1.000 & 1.000 \\
\hline Post & 99,772 & 0.412 & 0.492 & 0.000 & 0.000 & 1.000 \\
\hline Amihud & 99,772 & -0.994 & 5.260 & -0.050 & -0.005 & -0.001 \\
\hline Log Amihud & 99,772 & -0.197 & 0.607 & -0.049 & -0.005 & -0.001 \\
\hline Spread & 99,772 & -0.530 & 0.988 & -0.457 & -0.140 & -0.054 \\
\hline Log Spread & 99,772 & -0.312 & 0.414 & -0.376 & -0.131 & -0.052 \\
\hline Turnover & 99,772 & 0.011 & 0.021 & 0.003 & 0.006 & 0.011 \\
\hline Log Turnover & 99,772 & 0.011 & 0.020 & 0.003 & 0.006 & 0.011 \\
\hline Dollar Volume (\$1MM) & 99,772 & 29.668 & 77.956 & 0.417 & 2.641 & 17.793 \\
\hline Log Dollar Volume & 99,772 & 14.764 & 2.554 & 12.940 & 14.787 & 16.694 \\
\hline \multicolumn{7}{|c|}{ Dependent Variables in Disclosure Analyses: } \\
\hline Earnings Guidance & 95,693 & 0.110 & 0.313 & 0.000 & 0.000 & 0.000 \\
\hline Guidance Precision & 98,405 & 0.383 & 1.029 & 0.000 & 0.000 & 0.000 \\
\hline Conference Call & 96,852 & 0.706 & 0.456 & 0.000 & 1.000 & 1.000 \\
\hline Call Readability (all) & 71,884 & -34.830 & 8.308 & -39.154 & -33.282 & -28.918 \\
\hline Gross File Size & 62,530 & 9.666 & 8.541 & 11.838 & 7.180 & 4.576 \\
\hline \multicolumn{7}{|c|}{ Control Variables (at the firm-quarter level): } \\
\hline Stock Return & 96,852 & 0.057 & 0.243 & -0.071 & 0.045 & 0.166 \\
\hline Stock Return Volatility & 96,852 & 0.026 & 0.022 & 0.014 & 0.020 & 0.031 \\
\hline $\mathrm{B} / \mathrm{M}$ & 96,852 & 0.602 & 0.776 & 0.244 & 0.479 & 0.818 \\
\hline Size & 96,852 & 6.704 & 2.127 & 5.172 & 6.730 & 8.188 \\
\hline Earnings Volatility & 96,852 & 0.039 & 0.231 & 0.005 & 0.012 & 0.031 \\
\hline$R \& D$ & 96,852 & 0.348 & 0.476 & 0.000 & 0.000 & 1.000 \\
\hline Analyst Coverage & 96,852 & 6.670 & 7.280 & 1.000 & 4.000 & 10.000 \\
\hline News & 96,852 & 0.549 & 0.498 & 0.000 & 1.000 & 1.000 \\
\hline Loss & 96,852 & 0.335 & 0.472 & 0.000 & 0.000 & 1.000 \\
\hline Analyst Dispersion & 96,852 & 0.003 & 0.007 & 0.000 & 0.001 & 0.002 \\
\hline External Financing & 96,852 & 0.395 & 0.489 & 0.000 & 0.000 & 1.000 \\
\hline Litigation & 96,852 & 0.133 & 0.137 & 0.010 & 0.079 & 0.246 \\
\hline Competition & 96,852 & 0.641 & 0.447 & 0.334 & 0.616 & 0.932 \\
\hline
\end{tabular}


Table 1 (continued)

Notes: This table reports descriptive statistics for the main variables used in stock liquidity and disclosure analyses. Appendix B contains variable definitions. The sample period is 2012-2018. 
Table 2

Impact of Mutual Fund Liquidity Management on Portfolio Firms' Stock Liquidity

\begin{tabular}{|c|c|c|c|c|c|c|}
\hline & \multicolumn{6}{|c|}{ Dependent Variable: Stock Liquidity Measures } \\
\hline & \multicolumn{2}{|c|}{ Baseline Model } & \multicolumn{2}{|c|}{ Parallel Trends } & \multicolumn{2}{|c|}{ Firm Fixed Effects } \\
\hline & Log Amihud & Log Spread & Log Amihud & Log Spread & Log Amihud & Log Spread \\
\hline & $(1)$ & $(2)$ & $(3)$ & $(4)$ & $(5)$ & (6) \\
\hline Treat $\times$ Post & $0.049 * * *$ & $0.019 * * *$ & $0.063 * * *$ & $0.027 * * *$ & $0.058 * * *$ & $0.027 * * *$ \\
\hline & $(5.49)$ & $(4.22)$ & $(3.79)$ & $(3.54)$ & $(7.95)$ & $(7.25)$ \\
\hline Treat & $\begin{array}{c}0.208 * * * \\
(14.10)\end{array}$ & $\begin{array}{c}0.140 * * * \\
(16.85)\end{array}$ & $\begin{array}{l}0.020 \\
(0.85)\end{array}$ & $\begin{array}{l}0.009 \\
(0.86)\end{array}$ & & \\
\hline Treat $\times$ Pre2 & & & $\begin{array}{l}-0.018 \\
(-1.25)\end{array}$ & $\begin{array}{l}-0.001 \\
(-0.11)\end{array}$ & & \\
\hline Treat $\times$ Pre 1 & & & $\begin{array}{l}0.006 \\
(0.37)\end{array}$ & $\begin{array}{l}0.008 \\
(1.01)\end{array}$ & & \\
\hline Size & $\begin{array}{c}0.107 * * * \\
(33.36)\end{array}$ & $\begin{array}{c}0.101 * * * \\
(53.69)\end{array}$ & $\begin{array}{c}0.112 * * * \\
(32.08)\end{array}$ & $\begin{array}{c}0.104 * * * \\
(52.45)\end{array}$ & $\begin{array}{c}0.123 * * * \\
(23.96)\end{array}$ & $\begin{array}{c}0.112 * * * \\
(39.31)\end{array}$ \\
\hline Stock Return Volatility & $\begin{array}{c}-4.785 * * * \\
(-10.78)\end{array}$ & $\begin{array}{c}-5.506^{* * *} \\
(-24.04)\end{array}$ & $\begin{array}{c}-5.412 * * * \\
(-11.91)\end{array}$ & $\begin{array}{c}-5.913 * * * \\
(-25.30)\end{array}$ & $\begin{array}{c}-1.208 * * * \\
(-4.22)\end{array}$ & $\begin{array}{c}-2.480 * * * \\
(-16.78)\end{array}$ \\
\hline Analyst Coverage & $\begin{array}{c}-0.003 * * * \\
(-4.59)\end{array}$ & $\begin{array}{c}0.004 * * * \\
(6.84)\end{array}$ & $\begin{array}{l}0.000 \\
(0.52)\end{array}$ & $\begin{array}{c}0.006^{* * *} \\
(10.97)\end{array}$ & $\begin{array}{l}0.001 \\
(1.50)\end{array}$ & $\begin{array}{c}0.006 * * * \\
(15.31)\end{array}$ \\
\hline Intercept & $\begin{array}{c}-1.131 * * * \\
(-7.46)\end{array}$ & $\begin{array}{c}-1.111 \text { *** } \\
(-12.40)\end{array}$ & $\begin{array}{c}-1.046 * * * \\
(-6.28)\end{array}$ & $\begin{array}{c}-1.052 * * * \\
(-10.52)\end{array}$ & & \\
\hline Year-Quarter Fixed Effects & Yes & Yes & Yes & Yes & Yes & Yes \\
\hline
\end{tabular}


Table 2 (continued)

\begin{tabular}{lcccccc}
\hline Industry Fixed Effects & Yes & Yes & Yes & Yes & No & No \\
Firm Fixed Effects & No & No & No & No & Yes & Yes \\
Firm Clustered SE & Yes & Yes & Yes & Yes & 99,435 \\
\# of Observations & 99,772 & 99,772 & 99,772 & 99,772 & 99,435 \\
Adj. R-Squared & 0.283 & 0.570 & 0.263 & 0.552 & 0.734 & 0.888 \\
\hline \hline
\end{tabular}

Notes: This table reports results on the effect of mutual fund liquidity management on stock liquidity. Log Amihud is the natural logarithm of one plus quarterly Amihud for each fiscal quarter, where Amihud is the quarterly average of a stock's daily stock liquidity developed in Amihud (2002). Log Spread is the natural logarithm of one plus quarterly Spread for each fiscal quarter, where Spread is the quarterly average of a stock's daily bid-ask spread. Columns (1) and (2) report the main effect, Columns (3) and (4) validate the assumption of parallel trends, and Columns (5) and (6) estimate a firm fixed effects specification. In the firm fixed effects specification, singleton firms (i.e., firms with only one observation in the sample) are dropped to avoid underestimating standard errors and overstating statistical significance (Correia 2015; deHaan et al. 2017). The $t$-statistics reported in parentheses are based on standard errors clustered by firm. $* * *, * *$, and $*$ indicate significance at the $1 \%, 5 \%$, and $10 \%$ levels, respectively, using two-tailed tests. Appendix B contains variable definitions. 
Table 3

Impact of Mutual Fund Liquidity Management on Stock Liquidity:

Groups of Mutual Funds

Panel A. Pre-Treatment Portfolio Liquidity of Mutual Funds

\begin{tabular}{|c|c|c|c|c|}
\hline & \multicolumn{4}{|c|}{ Dependent Variable: Stock Liquidity Measures } \\
\hline & \multicolumn{2}{|c|}{ Log Amihud } & \multicolumn{2}{|c|}{ Log Spread } \\
\hline & (1) & (2) & (3) & (4) \\
\hline Treat_IlliquidFunds & $\begin{array}{c}-0.071 * * * * \\
(-2.85)\end{array}$ & & $\begin{array}{c}-0.103 * * * * \\
(-7.75)\end{array}$ & \\
\hline Post $\times$ Treat_IlliquidFunds & $0.065 * * *$ & $0.036 * *$ & $0.021 * *$ & $0.018 * *$ \\
\hline Treat_LiquidFunds & $\begin{array}{c}(3.68) \\
0.227 * * * \\
(11.17)\end{array}$ & $(2.42)$ & $\begin{array}{c}(2.34) \\
0.275^{* * * *} \\
(24.49)\end{array}$ & $(2.39)$ \\
\hline Post $\times$ Treat_LiquidFunds & -0.009 & 0.021 & -0.002 & 0.004 \\
\hline & $(-0.53)$ & $(1.45)$ & $(-0.25)$ & $(0.54)$ \\
\hline Control Variables & Included & Included & Included & Included \\
\hline Year-Quarter Fixed Effects & Yes & Yes & Yes & Yes \\
\hline Industry Fixed Effects & Yes & No & Yes & No \\
\hline Firm Fixed Effects & No & Yes & No & Yes \\
\hline Firm Clustered SE & Yes & Yes & Yes & Yes \\
\hline \# of Observations & 99,772 & 99,435 & 99,772 & 99,435 \\
\hline Adj. R-Squared & 0.276 & 0.734 & 0.589 & 0.888 \\
\hline
\end{tabular}


Table 3 (continued)

Panel B. Index and Outsourced Funds

\begin{tabular}{|c|c|c|c|c|}
\hline & \multicolumn{4}{|c|}{ Dependent Variable: Stock Liquidity Measures } \\
\hline & \multicolumn{2}{|c|}{ Log Amihud } & \multicolumn{2}{|c|}{ Log Spread } \\
\hline & (1) & (2) & (3) & (4) \\
\hline Post $\times$ Treat_IndexFunds & $\begin{array}{l}0.010 \\
(0.90)\end{array}$ & & $\begin{array}{l}0.002 \\
(0.36)\end{array}$ & \\
\hline Post $\times$ Treat_NonIndexFunds & $0.054 * * *$ & & $0.026 * * *$ & \\
\hline & $(4.56)$ & & $(4.56)$ & \\
\hline Post $\times$ Treat_Outsourced & & $\begin{array}{l}-0.001 \\
(-0.08)\end{array}$ & & $\begin{array}{l}0.008 \\
(1.35)\end{array}$ \\
\hline Post $\times$ Treat_In-House & & $0.058 * * *$ & & $0.022 * * *$ \\
\hline & & $(4.61)$ & & $(3.55)$ \\
\hline Control Variables & Included & Included & Included & Included \\
\hline Year-Quarter Fixed Effects & Yes & Yes & Yes & Yes \\
\hline Firm Fixed Effects & Yes & Yes & Yes & Yes \\
\hline Firm Clustered SE & Yes & Yes & Yes & Yes \\
\hline \# of Observations & 99,435 & 99,435 & 99,435 & 99,435 \\
\hline Adj. R-Squared & 0.734 & 0.734 & 0.888 & 0.888 \\
\hline
\end{tabular}

Notes: This table presents evidence on cross-sectional variations of the effect of mutual fund liquidity management on stock liquidity. In the firm fixed effects specification, singleton firms (i.e., firms with only one observation in the sample) are dropped to avoid underestimating standard errors and overstating statistical significance (Correia 2015; deHaan et al. 2017). The $t$-statistics reported in parentheses are based on standard errors clustered by firm. $* * *, * *$, and $*$ indicate significance at the $1 \%, 5 \%$, and $10 \%$ levels, respectively, using two-tailed tests. Appendix B contains variable definitions. 
Table 4

Impact of Mutual Fund Liquidity Management on Stock Liquidity:

Subsamples of Stocks

Panel A. Pre-Treatment Stock Liquidity

\begin{tabular}{|c|c|c|c|c|}
\hline & \multicolumn{4}{|c|}{ Dependent Variable: Stock Liquidity Measures } \\
\hline & \multicolumn{2}{|c|}{ Log Amihud } & \multicolumn{2}{|c|}{ Log Spread } \\
\hline & $(1)$ & (2) & (3) & (4) \\
\hline & \multicolumn{2}{|c|}{$\begin{array}{c}\text { Pre-Treatment } \\
\text { Log Amihud }\end{array}$} & \multicolumn{2}{|c|}{$\begin{array}{c}\text { Pre-Treatment } \\
\text { Log Spread }\end{array}$} \\
\hline & $\begin{array}{c}\text { Low } \\
\text { Liquidity }\end{array}$ & $\begin{array}{c}\text { High } \\
\text { Liquidity }\end{array}$ & $\begin{array}{c}\text { Low } \\
\text { Liquidity }\end{array}$ & $\begin{array}{c}\text { High } \\
\text { Liquidity }\end{array}$ \\
\hline Predicted Sign & + & & + & \\
\hline \multirow[t]{2}{*}{ Treat $\times$ Post } & $0.0799 * * *$ & -0.0002 & $0.0435 * * *$ & 0.0006 \\
\hline & $(6.06)$ & $(-0.50)$ & $(5.91)$ & $(0.36)$ \\
\hline Control Variables & Included & Included & Included & Included \\
\hline Year-Quarter Fixed Effects & Yes & Yes & Yes & Yes \\
\hline Firm Fixed Effects & Yes & Yes & Yes & Yes \\
\hline Firm Clustered SE & Yes & Yes & Yes & Yes \\
\hline \# of Observations & 48,472 & 47,967 & 48,411 & 48,046 \\
\hline Adj. R-Squared & 0.713 & 0.187 & 0.848 & 0.557 \\
\hline \multicolumn{5}{|c|}{ Test of difference in Treat $\times$ Post coefficients: } \\
\hline Difference & \multicolumn{2}{|c|}{$0.080 * * *$} & \multicolumn{2}{|c|}{$0.043 * * *$} \\
\hline$p$-value & \multicolumn{2}{|c|}{$<0.001$} & \multicolumn{2}{|c|}{$<0.001$} \\
\hline
\end{tabular}


Table 4 (continued)

Panel B. Pre-Treatment Information Asymmetry Measured by Analyst Coverage

\begin{tabular}{|c|c|c|c|c|}
\hline & \multicolumn{4}{|c|}{ Dependent Variable: Stock Liquidity Measures } \\
\hline & \multicolumn{2}{|c|}{ Log Amihud } & \multicolumn{2}{|c|}{ Log Spread } \\
\hline & (1) & $(2)$ & (3) & (4) \\
\hline & \multicolumn{2}{|c|}{ Analyst Coverage } & \multicolumn{2}{|c|}{ Analyst Coverage } \\
\hline & $\begin{array}{c}\text { Low } \\
\text { Coverage }\end{array}$ & $\begin{array}{c}\text { High } \\
\text { Coverage }\end{array}$ & $\begin{array}{c}\text { Low } \\
\text { Coverage }\end{array}$ & $\begin{array}{c}\text { High } \\
\text { Coverage }\end{array}$ \\
\hline Predicted Sign & + & & + & \\
\hline \multirow[t]{2}{*}{ Treat $\times$ Post } & $0.0608 * * *$ & $0.0273 * * *$ & $0.0212 * *$ & 0.0133 \\
\hline & $(3.43)$ & $(2.73)$ & $(2.30)$ & $(1.61)$ \\
\hline Control Variables & Included & Included & Included & Included \\
\hline Year-Quarter Fixed Effects & Yes & Yes & Yes & Yes \\
\hline Firm Fixed Effects & Yes & Yes & Yes & Yes \\
\hline Firm Clustered SE & Yes & Yes & Yes & Yes \\
\hline \# of Observations & 50,576 & 48,859 & 50,576 & 48,859 \\
\hline Adj. R-Squared & 0.731 & 0.472 & 0.890 & 0.827 \\
\hline \multicolumn{5}{|c|}{ Test of difference in Treat $\times$ Post coefficients: } \\
\hline Difference & \multicolumn{2}{|c|}{$0.034 * * *$} & \multicolumn{2}{|c|}{$0.008 * * *$} \\
\hline$p$-value & \multicolumn{2}{|c|}{$<0.001$} & \multicolumn{2}{|c|}{$<0.001$} \\
\hline
\end{tabular}


Table 4 (continued)

Panel C. Pre-Treatment Information Asymmetry Measured by Market Cap

\begin{tabular}{|c|c|c|c|c|}
\hline & \multicolumn{4}{|c|}{ Dependent Variable: Stock Liquidity Measures } \\
\hline & \multicolumn{2}{|c|}{ Log Amihud } & \multicolumn{2}{|c|}{ Log Spread } \\
\hline & (1) & (2) & (3) & (4) \\
\hline & \multicolumn{2}{|c|}{ Market Capitalization } & \multicolumn{2}{|c|}{ Market Capitalization } \\
\hline & Small & Large & Small & Large \\
\hline Predicted Sign & + & & + & \\
\hline \multirow[t]{2}{*}{ Treat $\times$ Post } & $0.0799 * * *$ & $0.0082 * *$ & $0.0396 * * *$ & $0.0085 * * *$ \\
\hline & $(5.89)$ & $(2.53)$ & $(5.27)$ & (3.04) \\
\hline Control Variables & Included & Included & Included & Included \\
\hline Year-Quarter Fixed Effects & Yes & Yes & Yes & Yes \\
\hline Firm Fixed Effects & Yes & Yes & Yes & Yes \\
\hline Firm Clustered SE & Yes & Yes & Yes & Yes \\
\hline \# of Observations & 48,939 & 48,615 & 48,939 & 48,615 \\
\hline Adj. R-Squared & 0.714 & 0.699 & 0.857 & 0.786 \\
\hline \multicolumn{5}{|c|}{ Test of difference in Treat $\times$ Post coefficients: } \\
\hline Difference & \multicolumn{2}{|c|}{$0.072 * * *$} & \multicolumn{2}{|c|}{$0.031 * * *$} \\
\hline$p$-value & \multicolumn{2}{|c|}{$<0.001$} & \multicolumn{2}{|c|}{$<0.001$} \\
\hline
\end{tabular}

Notes: This table presents evidence on cross-sectional variations of the effect of mutual fund liquidity management on stock liquidity. In the firm fixed effects specification, singleton firms (i.e., firms with only one observation in the sample) are dropped to avoid underestimating standard errors and overstating statistical significance (Correia 2015; deHaan et al. 2017). The $t$-statistics reported in parentheses are based on standard errors clustered by firm. $* * *, * *$, and $*$ indicate significance at the $1 \%, 5 \%$, and $10 \%$ levels, respectively, using two-tailed tests. Appendix B contains variable definitions. 
Table 5

Possible Mechanism: Management Forecasts

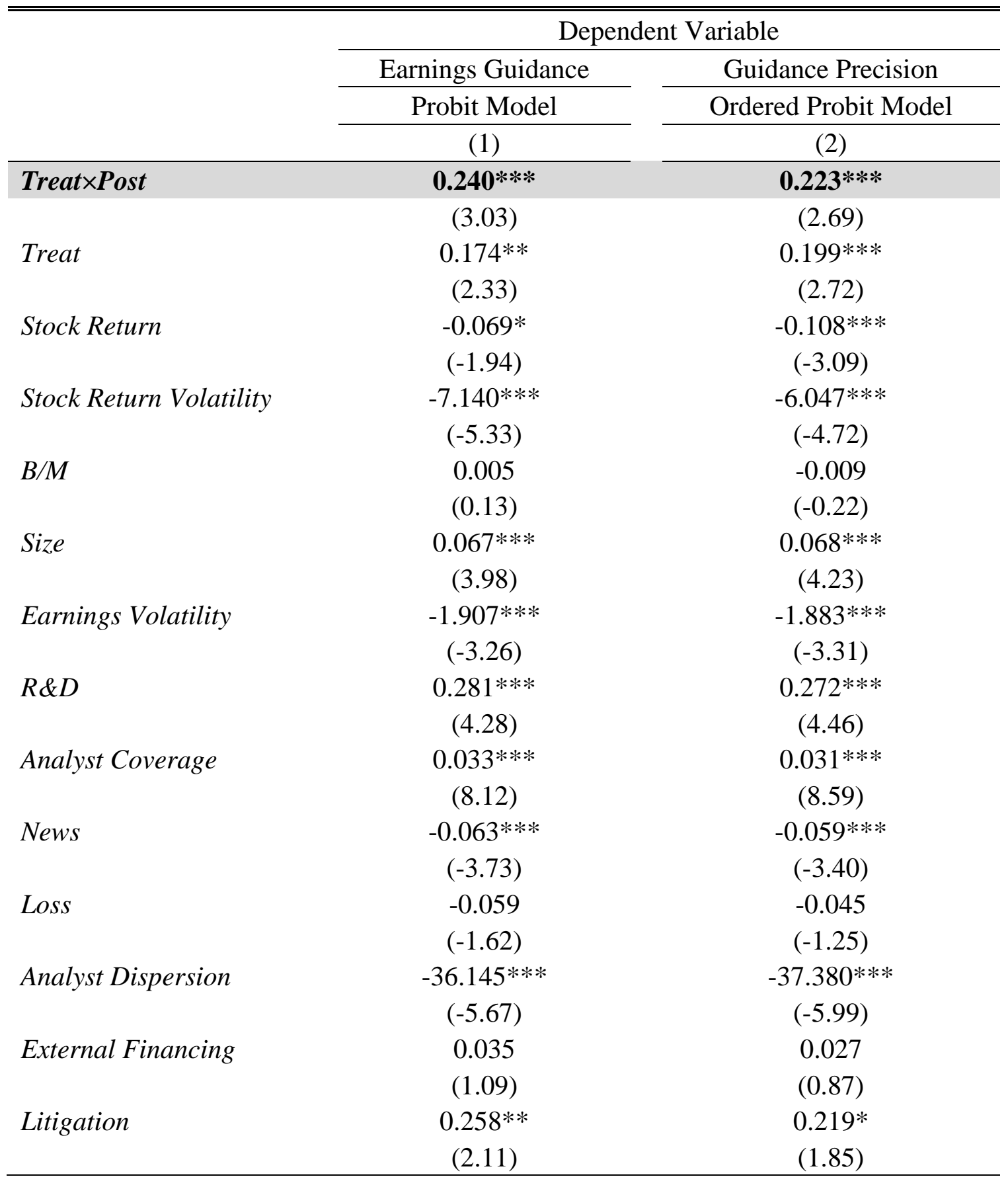

(Continued) 
Table 5 (continued)

\begin{tabular}{lcc}
\hline Competition & $0.455^{* * *}$ & $0.409 * * *$ \\
& $(8.80)$ & $(8.13)$ \\
Intercept & $-2.802 * * *$ & \\
& $(-9.55)$ & \\
Year-Quarter Fixed Effects & Yes & Yes \\
Industry Fixed Effects & Yes & N/A \\
Firm Fixed Effects & N/A & Yes \\
Firm Clustered SE & Yes & 98,405 \\
\# of Observations & 95,693 & 0.249 \\
Pseudo R-Squared & 0.283 & \\
\hline \hline
\end{tabular}

Notes: This table presents evidence on the effect of mutual fund liquidity management on management forecasts. Earnings Guidance is an indicator variable that equals one if the firm issues at least one management quarterly earnings forecast in the fiscal quarter and zero otherwise. Guidance Precision measures the precision of management quarterly earnings forecasts issued in the fiscal quarter. Guidance Precision equals 4 if the forecast is a point forecast, 3 if the forecast is a range forecast, 2 if the forecast is an open-ended forecast, 1 if the forecast is a qualitative forecast, and 0 if there is no forecast in the fiscal quarter. Firm fixed effects in probit and ordered probit models are not included to avoid the incidental parameter problem. The $t$-statistics reported in parentheses are based on standard errors clustered by firm. $* * *, * *$, and $*$ indicate significance at the $1 \%, 5 \%$, and $10 \%$ levels, respectively, using two-tailed tests. Appendix B contains variable definitions. 
Table 6

Possible Mechanism: Conference Calls

Panel A. Indicator of Conference Calls

\begin{tabular}{|c|c|}
\hline \multicolumn{2}{|c|}{ Dependent Variable: Conference Call } \\
\hline & Probit Model \\
\hline \multirow[t]{2}{*}{ Treat $\times$ Post } & $0.280 * * *$ \\
\hline & $(5.92)$ \\
\hline \multirow[t]{2}{*}{ Treat } & $0.162 * * *$ \\
\hline & $(3.57)$ \\
\hline \multirow[t]{2}{*}{ Stock Return } & -0.013 \\
\hline & $(-0.50)$ \\
\hline \multirow[t]{2}{*}{ Stock Return Volatility } & $-2.344 * * *$ \\
\hline & $(-4.74)$ \\
\hline \multirow[t]{2}{*}{$B / M$} & -0.000 \\
\hline & $(-0.02)$ \\
\hline \multirow[t]{2}{*}{ Size } & $0.149 * * *$ \\
\hline & $(11.34)$ \\
\hline \multirow[t]{2}{*}{ Earnings Volatility } & $-0.269 * * *$ \\
\hline & $(-4.28)$ \\
\hline \multirow[t]{2}{*}{$R \& D$} & $0.194 * * *$ \\
\hline & $(4.06)$ \\
\hline \multirow[t]{2}{*}{ Analyst Coverage } & $0.067 * * *$ \\
\hline & $(9.77)$ \\
\hline \multirow[t]{2}{*}{ News } & $0.033 * *$ \\
\hline & $(2.49)$ \\
\hline \multirow[t]{2}{*}{ Loss } & $0.061 * *$ \\
\hline & $(2.30)$ \\
\hline \multirow[t]{2}{*}{ Analyst Dispersion } & $15.586^{* * *}$ \\
\hline & $(7.21)$ \\
\hline \multirow[t]{2}{*}{ External Financing } & 0.015 \\
\hline & $(0.65)$ \\
\hline \multirow[t]{2}{*}{ Litigation } & $0.985 * * *$ \\
\hline & $(10.54)$ \\
\hline
\end{tabular}

(Continued) 
Table 6 (continued)

\begin{tabular}{lc}
\hline Competition & $0.245^{* * *}$ \\
& $(6.28)$ \\
Intercept & $-2.204^{* * *}$ \\
& $(-7.17)$ \\
Year-Quarter Fixed Effects & Yes \\
Industry Fixed Effects & Yes \\
Firm Fixed Effects & N/A \\
Firm Clustered SE & Yes \\
\# of Observations & 96,852 \\
Pseudo R-Squared & 0.292 \\
\hline \hline
\end{tabular}

Panel B. Readability of Conference Calls

\begin{tabular}{|c|c|c|c|c|c|c|}
\hline \multirow{4}{*}{ Rea } & \multicolumn{6}{|c|}{ Dependent Variable: Call Readability } \\
\hline & \multicolumn{6}{|c|}{ dability $=(-1) \times$ Gunning Fog Index (higher value indicates higher readability) } \\
\hline & \multicolumn{2}{|c|}{ Presentation + Answers } & \multicolumn{2}{|c|}{ Presentation } & \multicolumn{2}{|c|}{ Answers } \\
\hline & (1) & (2) & (3) & (4) & (5) & (6) \\
\hline \multirow[t]{2}{*}{ Treat $\times$ Post } & $1.832 * * *$ & $1.462 * * *$ & $0.602 * * *$ & $0.449 * * *$ & $3.255 * * *$ & $2.657 * * *$ \\
\hline & -10.59 & -8.09 & -4.58 & -3.23 & -10.24 & -8.27 \\
\hline Treat & $\begin{array}{c}-0.561 * * * \\
(-3.29)\end{array}$ & & $\begin{array}{l}-0.094 \\
(-0.80)\end{array}$ & & $\begin{array}{c}-1.413 * * * \\
(-4.15)\end{array}$ & \\
\hline \multirow[t]{2}{*}{ Stock Return } & $0.568^{* * * *}$ & 0.236 & $0.408 * * *$ & $0.283^{* *}$ & $0.924 * * *$ & $0.480^{* *}$ \\
\hline & -4.02 & -1.63 & -3.32 & -2.15 & -3.76 & -2.02 \\
\hline \multirow[t]{2}{*}{ Stock Return Volatility } & $-10.337 * * *$ & -3.067 & $-6.715^{* * *}$ & $-5.473 * *$ & -4.805 & 0.105 \\
\hline & $(-3.31)$ & $(-1.00)$ & $(-2.59)$ & $(-2.09)$ & $(-0.83)$ & -0.02 \\
\hline \multirow[t]{2}{*}{$B / M$} & $0.478^{* * * *}$ & -0.101 & $0.272 * * *$ & -0.175 & $1.030^{* * * *}$ & -0.269 \\
\hline & -4.24 & $(-0.61)$ & -3.09 & $(-1.32)$ & -4.88 & $(-0.98)$ \\
\hline \multirow[t]{2}{*}{ Size } & $-0.515^{* * * *}$ & $-0.255^{* *}$ & $-0.197 * * *$ & $-0.211 * *$ & $-1.053 * * *$ & $-0.760 * * *$ \\
\hline & $(-9.79)$ & $(-2.12)$ & $(-5.10)$ & $(-2.22)$ & $(-10.99)$ & $(-3.52)$ \\
\hline \multirow[t]{2}{*}{ Earnings Volatility } & $-3.707 * * *$ & 2.767 & $-3.896 * * *$ & -0.517 & -3.768 & $6.098 * *$ \\
\hline & $(-2.62)$ & -1.53 & $(-3.60)$ & $(-0.34)$ & $(-1.36)$ & -2.04 \\
\hline \multirow[t]{2}{*}{$R \& D$} & -0.042 & -0.199 & 0.203 & -0.087 & -0.329 & -0.252 \\
\hline & $(-0.24)$ & $(-0.98)$ & -1.58 & $(-0.47)$ & $(-0.98)$ & $(-0.77)$ \\
\hline \multirow[t]{2}{*}{ Analyst Coverage } & $-0.071 * * *$ & $-0.046^{* *}$ & 0.001 & 0.014 & $-0.132 * * *$ & $-0.135 * * *$ \\
\hline & $(-6.01)$ & $(-2.56)$ & -0.11 & -0.98 & $(-6.13)$ & $(-4.40)$ \\
\hline
\end{tabular}

(Continued) 
Table 6 (continued)

\begin{tabular}{lcccccc}
\hline News & 0.019 & 0.04 & 0.051 & 0.052 & 0.084 & 0.105 \\
& -0.27 & -0.62 & -0.83 & -0.87 & -0.69 & -1.02 \\
Loss & $-0.627 * * *$ & 0.027 & $-0.376^{* * *}$ & 0.067 & $-0.932^{* * *}$ & 0.021 \\
& $(-5.70)$ & -0.27 & $(-4.31)$ & -0.74 & $(-4.57)$ & -0.13 \\
Analyst Dispersion & -5.789 & 5.605 & 0.071 & 6.194 & $-38.68^{* * *}$ & -11.53 \\
& $(-0.95)$ & -0.91 & -0.01 & -1.04 & $(-3.65)$ & $(-1.12)$ \\
External Financing & 0.057 & -0.122 & -0.02 & -0.104 & 0.072 & -0.161 \\
& -0.61 & $(-1.32)$ & $(-0.27)$ & $(-1.33)$ & -0.42 & $(-1.02)$ \\
Litigation & $-1.568^{* * *}$ & $-0.622 *$ & $-0.588^{* *}$ & -0.008 & $-2.922^{* * *}$ & $-1.697 * * *$ \\
& $(-4.29)$ & $(-1.74)$ & $(-2.16)$ & $(-0.03)$ & $(-4.32)$ & $(-2.89)$ \\
Competition & -0.142 & -0.167 & -0.027 & 0.043 & -0.272 & -0.379 \\
& $(-1.02)$ & $(-0.79)$ & $(-0.27)$ & -0.24 & $(-1.04)$ & $(-1.03)$ \\
Intercept & $-30.00^{* * *}$ & & $-32.64 * * *$ & & $-26.15^{* * *}$ & \\
& $(-17.23)$ & & $(-22.40)$ & & $(-10.70)$ & \\
Year-Quarter FE & Yes & Yes & Yes & Yes & Yes & Yes \\
Industry FE & Yes & No & Yes & No & Yes & No \\
Firm FE & No & Yes & No & Yes & No & Yes \\
Firm Clustered SE & Yes & Yes & Yes & Yes & Yes & Yes \\
\# of Observations & 71,884 & 71,706 & 71,884 & 71,706 & 71,884 & 71,706 \\
Adj. R-Squared & 0.081 & 0.228 & 0.019 & 0.101 & 0.119 & 0.327 \\
\hline \hline
\end{tabular}

Notes: This table presents evidence on the effect of mutual fund liquidity management on conference calls. Conference Call is an indicator variable that equals one if the firm holds at least one conference call in the fiscal quarter and zero otherwise. Call Readability is the Gunning Fog index of the conference call transcripts, multiplied by (-1). Firm fixed effects are not included in probit models to avoid the incidental parameter problem. In the firm fixed effects specification, singleton firms (i.e., firms with only one observation in the sample) are dropped to avoid underestimating standard errors and overstating statistical significance (Correia 2015; deHaan et al. 2017). The $t$-statistics reported in parentheses are based on standard errors clustered by firm. $* * *, * *$, and $*$ indicate significance at the $1 \%$, $5 \%$, and $10 \%$ levels, respectively, using two-tailed tests. Appendix B contains variable definitions. 
Table 7

Possible Mechanism: Mandatory Disclosure

\begin{tabular}{|c|c|c|}
\hline \multicolumn{3}{|c|}{ Dependent Variable: Quarterly Report Readability } \\
\hline \multicolumn{3}{|c|}{$\begin{array}{c}\text { Readability Measure Developed by Loughran and McDonald (2014) } \\
\text { (higher value indicates higher readability) }\end{array}$} \\
\hline & \multicolumn{2}{|c|}{$(-1) \times$ Gross File Size } \\
\hline & $(1)$ & $(2)$ \\
\hline Treat $\times$ Post & $0.614 * * *$ & $0.371 * *$ \\
\hline & $(3.98)$ & $(2.56)$ \\
\hline Treat & $\begin{array}{l}0.019 \\
(0.08)\end{array}$ & \\
\hline Stock Return & $\begin{array}{c}1.285 * * * \\
(10.83)\end{array}$ & $\begin{array}{l}0.360 * * * \\
(5.01)\end{array}$ \\
\hline Stock Return Volatility & $\begin{array}{c}-16.663 * * * \\
\quad(-3.76)\end{array}$ & $\begin{array}{l}-3.091 * * \\
(-1.96)\end{array}$ \\
\hline$B / M$ & $\begin{array}{l}-0.952 * * * \\
(-7.39)\end{array}$ & $\begin{array}{l}-0.152 * * \\
(-2.29)\end{array}$ \\
\hline Size & $\begin{array}{l}-1.445^{* * *} \\
(-16.80)\end{array}$ & $\begin{array}{l}-0.076 \\
(-1.11)\end{array}$ \\
\hline Earnings Volatility & $\begin{array}{l}0.644 * * * \\
(2.86)\end{array}$ & $\begin{array}{l}0.033 \\
(0.53)\end{array}$ \\
\hline$R \& D$ & $\begin{array}{l}0.273 * \\
(1.69)\end{array}$ & $\begin{array}{c}-0.464 * * * \\
(-6.43)\end{array}$ \\
\hline Analyst Coverage & $\begin{array}{l}0.004 \\
(0.21)\end{array}$ & $\begin{array}{c}-0.045 * * * \\
(-2.90)\end{array}$ \\
\hline News & $\begin{array}{l}-0.019 \\
(-0.28)\end{array}$ & $\begin{array}{l}-0.032 \\
(-0.92)\end{array}$ \\
\hline Loss & $\begin{array}{c}-0.732 * * * \\
(-6.29)\end{array}$ & $\begin{array}{l}-0.059 \\
(-1.00)\end{array}$ \\
\hline Analyst Dispersion & $\begin{array}{c}-79.123 * * * \\
(-9.44)\end{array}$ & $\begin{array}{c}-11.383 * * * \\
(-2.75)\end{array}$ \\
\hline External Financing & $\begin{array}{c}-0.406 * * * \\
(-3.34)\end{array}$ & $\begin{array}{l}-0.094 \\
(-1.45)\end{array}$ \\
\hline Litigation & $\begin{array}{c}-5.453 * * * \\
(-9.52) \\
\end{array}$ & $\begin{array}{c}-1.094 * * * \\
(-5.10)\end{array}$ \\
\hline
\end{tabular}


Table 7 (continued)

\begin{tabular}{lcc}
\hline Competition & $1.897^{* * *}$ & $0.207^{* *}$ \\
& $(9.54)$ & $(2.21)$ \\
Intercept & $3.322^{* * *}$ & \\
& $(4.19)$ & \\
Year-Quarter FE & Yes & Yes \\
Industry FE & Yes & No \\
Firm FE & No & Yes \\
Firm Clustered SE & Yes & Yes \\
\# of Observations & 62,530 & 62,435 \\
Pseudo R-Squared & 0.415 & 0.824 \\
\hline \hline
\end{tabular}

Notes: This table presents evidence on the effect of mutual fund liquidity management on quarterly report readability. Quarterly Report Readability is the text document file size (in megabytes) of the firm's 10-Q filed in the fiscal quarter, multiplied by (-1). In the firm fixed effects specification, singleton firms (i.e., firms with only one observation in the sample) are dropped to avoid underestimating standard errors and overstating statistical significance (Correia 2015; deHaan et al. 2017). The $t$-statistics reported in parentheses are based on standard errors clustered by firm. $* * *, * *$, and $*$ indicate significance at the $1 \%$, $5 \%$, and $10 \%$ levels, respectively, using two-tailed tests. Appendix B contains variable definitions. 
Table 8

Validation of A Possible Mechanism

Panel A. Individual Measures of Disclosure Improvement

\begin{tabular}{|c|c|c|c|c|c|}
\hline & \multicolumn{5}{|c|}{ Dependent Variable: Log Amihud } \\
\hline & $(1)$ & $(2)$ & $(3)$ & $(4)$ & $(5)$ \\
\hline Disclosure & $\begin{array}{l}\text { Earnings } \\
\text { Guidance }\end{array}$ & $\begin{array}{l}\text { Guidance } \\
\text { Precision }\end{array}$ & $\begin{array}{c}\text { Conference } \\
\text { Call }\end{array}$ & $\begin{array}{c}\text { Call } \\
\text { Readability }\end{array}$ & $\begin{array}{c}\text { Quarterly } \\
\text { Report } \\
\text { Readability }\end{array}$ \\
\hline \multirow[t]{2}{*}{ Improved_Disclosure $\times$ Post } & $0.029 * * *$ & $0.026 * * *$ & $0.034 * * *$ & $0.037 * * *$ & $0.043 * * *$ \\
\hline & $(5.14)$ & $(4.66)$ & $(5.03)$ & $(6.56)$ & $(6.55)$ \\
\hline Control Variables & Yes & Yes & Yes & Yes & Yes \\
\hline Year-Quarter FE & Yes & Yes & Yes & Yes & Yes \\
\hline Firm FE & Yes & Yes & Yes & Yes & Yes \\
\hline Firm Clustered SE & Yes & Yes & Yes & Yes & Yes \\
\hline \# of Observations & 99,435 & 99,435 & 99,435 & 99,435 & 99,435 \\
\hline \multirow[t]{3}{*}{ Adj. R-Squared } & 0.733 & 0.733 & 0.733 & 0.733 & 0.733 \\
\hline & \multicolumn{5}{|c|}{ Dependent Variable: Log Spread } \\
\hline & $(6)$ & $(7)$ & $(8)$ & $(9)$ & $(10)$ \\
\hline Disclosure & $\begin{array}{l}\text { Earnings } \\
\text { Guidance }\end{array}$ & $\begin{array}{l}\text { Guidance } \\
\text { Precision }\end{array}$ & $\begin{array}{c}\text { Conference } \\
\text { Call }\end{array}$ & $\begin{array}{c}\text { Call } \\
\text { Readability }\end{array}$ & $\begin{array}{c}\text { Quarterly } \\
\text { Report } \\
\text { Readability }\end{array}$ \\
\hline \multirow[t]{2}{*}{ Improved_Disclosure $\times$ Post } & $0.011 * *$ & $0.009 *$ & $0.026 * * *$ & $0.010 * * *$ & $0.016 * * *$ \\
\hline & $(2.27)$ & $(1.90)$ & $(6.02)$ & $(2.84)$ & $(4.29)$ \\
\hline Control Variables & Yes & Yes & Yes & Yes & Yes \\
\hline Year-Quarter FE & Yes & Yes & Yes & Yes & Yes \\
\hline Firm FE & Yes & Yes & Yes & Yes & Yes \\
\hline Firm Clustered SE & Yes & Yes & Yes & Yes & Yes \\
\hline \# of Observations & 99,435 & 99,435 & 99,435 & 99,435 & 99,435 \\
\hline Adj. R-Squared & 0.888 & 0.888 & 0.888 & 0.888 & 0.888 \\
\hline
\end{tabular}


Table 8 (continued)

Panel B. Composite Measures of Disclosure Improvement

\begin{tabular}{|c|c|c|c|c|}
\hline & \multicolumn{4}{|c|}{ Dependent Variable: Stock Liquidity Measures } \\
\hline & \multicolumn{2}{|c|}{ Log Amihud } & \multicolumn{2}{|c|}{ Log Spread } \\
\hline & (1) & (2) & (3) & (4) \\
\hline Improved_Disclosure $1 \times$ Post & $\begin{array}{c}\mathbf{0 . 0 5 5}^{* * * *} * \\
(7.82)\end{array}$ & & $\begin{array}{c}\mathbf{0 . 0 2 5}^{*} * * * \\
(6.80)\end{array}$ & \\
\hline Improved_Disclosure $2 \times$ Post & & $\begin{array}{c}\mathbf{0 . 0 3 8}^{* * * *} \\
(4.24)\end{array}$ & & $\begin{array}{c}\mathbf{0 . 0 1 5}^{* * * *} \\
(3.60)\end{array}$ \\
\hline Control Variables & Yes & Yes & Yes & Yes \\
\hline Year-Quarter FE & Yes & Yes & Yes & Yes \\
\hline Firm FE & Yes & Yes & Yes & Yes \\
\hline Firm Clustered SE & Yes & Yes & Yes & Yes \\
\hline \# of Observations & 99435 & 99435 & 99435 & 99435 \\
\hline Adj. R-Squared & 0.734 & 0.733 & 0.888 & 0.888 \\
\hline
\end{tabular}

Notes: This table examines whether the stock liquidity improvement is driven by disclosure improvement around the SEC proposal. Improved_Disclosure is an indicator variable that equals one if a specific dimension of a treatment firm's disclosure (earnings guidance likelihood, guidance precision, conference call likelihood, call readability, or quarterly report readability) is improved in the post-treatment period relative to the pre-treatment period, and zero otherwise. Improved_Disclosurel is an indicator variable that equals one if at least one dimension of a treatment firm's disclosure (earnings guidance likelihood, guidance precision, conference call likelihood, call readability, or quarterly report readability) is improved in the post-treatment period relative to the pre-treatment period, and zero otherwise. Improved_Disclosure2 is an indicator variable that equals one if at least one dimension of a treatment firm's disclosure (earnings guidance likelihood, guidance precision, conference call likelihood, call readability, or quarterly report readability) is improved and all other dimensions of disclosure do not become worse in the post-treatment period relative to the pre-treatment period, and zero otherwise. In the firm fixed effects specification, singleton firms (i.e., firms with only one observation in the sample) are dropped to avoid underestimating standard errors and overstating statistical significance (Correia 2015; deHaan et al. 2017). The $t$-statistics reported in parentheses are based on standard errors clustered by firm. $* * *, * *$, and $*$ indicate significance at the $1 \%$, $5 \%$, and $10 \%$ levels, respectively, using two-tailed tests. Appendix B contains variable definitions. 
Table 9

Proprietary Costs of Disclosure

\begin{tabular}{|c|c|c|c|c|}
\hline & \multicolumn{4}{|c|}{ Dependent Variable: Stock Liquidity Measures } \\
\hline & \multicolumn{2}{|c|}{ Log Amihud } & \multicolumn{2}{|c|}{ Log Spread } \\
\hline & (1) & $(2)$ & (3) & (4) \\
\hline & \multicolumn{2}{|c|}{$\begin{array}{c}\text { Proprietary Costs } \\
\text { of Disclosure }\end{array}$} & \multicolumn{2}{|c|}{$\begin{array}{c}\text { Proprietary Costs } \\
\text { of Disclosure }\end{array}$} \\
\hline & Low & High & Low & High \\
\hline Predicted Sign & + & & + & \\
\hline \multirow[t]{2}{*}{ Treat $\times$ Post } & $0.063 * * *$ & 0.021 & $0.024 * * *$ & 0.014 \\
\hline & $(8.11)$ & $(0.91)$ & $(4.57)$ & $(1.46)$ \\
\hline Control Variables & Included & Included & Included & Included \\
\hline Year-Quarter FE & Yes & Yes & Yes & Yes \\
\hline Firm FE & Yes & Yes & Yes & Yes \\
\hline Firm Clustered SE & Yes & Yes & Yes & Yes \\
\hline \# of Observations & 49,346 & 50,089 & 49,346 & 50,089 \\
\hline Adj. R-Squared & 0.729 & 0.737 & 0.875 & 0.900 \\
\hline \multicolumn{5}{|c|}{ Test of difference in Treat $\times$ Post coefficients: } \\
\hline Difference & \multicolumn{2}{|c|}{$0.042 * * *$} & \multicolumn{2}{|c|}{$0.010 * * *$} \\
\hline$p$-value & \multicolumn{2}{|c|}{$<0.001$} & \multicolumn{2}{|c|}{$<0.001$} \\
\hline
\end{tabular}

Notes: This table presents evidence on cross-sectional variations of the effect of mutual fund liquidity management on stock liquidity. Competition measured immediately before the SEC proposal is used to proxy for proprietary costs of disclosure. In the firm fixed effects specification, singleton firms (i.e., firms with only one observation in the sample) are dropped to avoid underestimating standard errors and overstating statistical significance (Correia 2015; deHaan et al. 2017). The $t$-statistics reported in parentheses are based on standard errors clustered by firm. $* * *, * *$, and $*$ indicate significance at the $1 \%$, $5 \%$, and $10 \%$ levels, respectively, using two-tailed tests. Appendix B contains variable definitions. 
Table 10

Continuous Treatment Variable

\begin{tabular}{lcccc}
\hline \hline & \multicolumn{2}{c}{ Log Amihud } & \multicolumn{2}{c}{ Log Spread } \\
\cline { 2 - 5 } Panel A & $(1)$ & $(2)$ & $(3)$ & $(4)$ \\
\hline Predicated Sign & + & + & + & + \\
TreatOwn×Post & $\mathbf{0 . 1 2 1} * * *$ & $\mathbf{0 . 1 3 9 * * *}$ & $\mathbf{0 . 0 3 7 * * *}$ & $\mathbf{0 . 0 5 1 * * *}$ \\
& $(5.90)$ & $(8.68)$ & $(3.41)$ & $(6.06)$ \\
TreatOwn & $0.397 * * *$ & & $0.456 * * *$ & \\
& $(14.34)$ & & $(23.96)$ & \\
Control Variables & Included & Included & Included & Included \\
Year-Quarter FE & Yes & Yes & Yes & Yes \\
Industry FE & Yes & No & Yes & No \\
Firm FE & No & Yes & No & Yes \\
Firm Clustered SE & Yes & Yes & Yes & Yes \\
\# of Observations & 99,772 & 99,435 & 99,772 & 99,435 \\
Adj./Pseudo R2 & 0.271 & 0.733 & 0.573 & 0.888 \\
\hline \hline
\end{tabular}

\begin{tabular}{lccccc}
\hline \hline & $\begin{array}{c}\text { Earnings } \\
\text { Guidance }\end{array}$ & $\begin{array}{c}\text { Guidance } \\
\text { Precision }\end{array}$ & $\begin{array}{c}\text { Conference } \\
\text { Call }\end{array}$ & \multicolumn{2}{c}{$\begin{array}{c}\text { Call Readability } \\
\text { (Presentation }+ \\
\text { Answers) }\end{array}$} \\
\cline { 2 - 6 } Panel B & $(1)$ & $(2)$ & $(3)$ & $(4)$ & $(5)$ \\
\hline Predicated Sign & + & + & + & + & + \\
TreatOwn×Post & $\mathbf{0 . 3 9 4 * * *}$ & $\mathbf{0 . 3 9 1 * * *}$ & $\mathbf{0 . 8 5 5 * * *}$ & $\mathbf{5 . 3 5 4 * * *}$ & $\mathbf{4 . 0 4 7 * * *}$ \\
& $(3.41)$ & $(3.37)$ & $(7.25)$ & $(10.43)$ & $(7.36)$ \\
TreatOwn & $1.356^{* * *}$ & $1.297^{* * *}$ & $1.395^{* * *}$ & $-1.638^{* * *}$ & \\
& $(8.31)$ & $(8.31)$ & $(11.71)$ & $(-3.27)$ & \\
Control Variables & Included & Included & Included & Included & Included \\
Year-Quarter FE & Yes & Yes & Yes & Yes & Yes \\
Industry FE & Yes & Yes & Yes & Yes & No \\
Firm FE & N/A & N/A & N/A & No & Yes \\
Firm Clustered SE & Yes & Yes & Yes & Yes & Yes \\
\# of Observations & 95,693 & 98,405 & 96,852 & 71,884 & 71,706 \\
Adj./Pseudo R2 & 0.298 & 0.262 & 0.307 & 0.081 & 0.228 \\
\hline \hline
\end{tabular}


Table 10 (continued)

\begin{tabular}{lcccccc}
\hline \hline & \multicolumn{2}{c}{$\begin{array}{c}\text { Call Readability } \\
\text { (Presentation) }\end{array}$} & \multicolumn{2}{c}{$\begin{array}{c}\text { Call Readability } \\
\text { (Answers) }\end{array}$} & \multicolumn{2}{c}{$\begin{array}{c}\text { Quarterly Report } \\
\text { Readability }\end{array}$} \\
\cline { 2 - 7 } Panel C & $(1)$ & $(2)$ & $(3)$ & $(4)$ & $(5)$ & $(6)$ \\
\hline Predicated Sign & + & + & + & + & + & + \\
TreatOwn $\times$ Post & $\mathbf{1 . 9 6 4 * * *}$ & $\mathbf{1 . 3 2 6 * * *}$ & $\mathbf{9 . 2 5 8 * * *}$ & $\mathbf{7 . 0 7 4}^{* * *}$ & $\mathbf{1 . 7 7 1}^{* * *}$ & $\mathbf{1 . 0 6 1 * * *}$ \\
& $(5.07)$ & $(3.16)$ & $(9.78)$ & $(7.15)$ & $(4.14)$ & $(2.59)$ \\
TreatOwn & -0.243 & & $-4.307^{* * *}$ & & $1.165^{*}$ & \\
& $(-0.71)$ & & $(-4.24)$ & & $(1.65)$ & \\
Control Variables & Included & Included & Included & Included & Included & Included \\
Year-Quarter FE & Yes & Yes & Yes & Yes & Yes & Yes \\
Industry FE & Yes & No & Yes & No & Yes & No \\
Firm FE & No & Yes & No & Yes & No & Yes \\
Firm Clustered SE & Yes & Yes & Yes & Yes & Yes & Yes \\
\# of Observations & 71,884 & 71,706 & 71,884 & 71,706 & 62,530 & 62,435 \\
Adj./Pseudo R2 & 0.020 & 0.101 & 0.119 & 0.326 & 0.416 & 0.824 \\
\hline \hline
\end{tabular}

Notes: This table reports difference-in-differences estimates using a continuous treatment variable (TreatOwn), i.e., mutual fund ownership measured immediately before the event date. In the firm fixed effects specification, singleton firms (i.e., firms with only one observation in the sample) are dropped to avoid underestimating standard errors and overstating statistical significance (Correia 2015; deHaan et al. 2017). The $t$-statistics reported in parentheses are based on standard errors clustered by firm. $* * *, * *$, and $*$ indicate significance at the $1 \%, 5 \%$, and $10 \%$ levels, respectively, using two-tailed tests. Appendix B contains variable definitions. 
Table 11

Placebo Tests: Placebo Date

\begin{tabular}{|c|c|c|c|c|}
\hline & \multicolumn{4}{|c|}{ Dependent Variable: Stock Liquidity Measures } \\
\hline & \multicolumn{2}{|c|}{ Log Amihud } & \multicolumn{2}{|c|}{ Log Spread } \\
\hline & $(1)$ & $(2)$ & (3) & (4) \\
\hline Treat $\times$ Post_Placebo & -0.017 & 0.007 & 0.002 & -0.001 \\
\hline & $(-1.16)$ & $(0.51)$ & $(0.25)$ & $(-0.15)$ \\
\hline Treat & $\begin{array}{c}0.180 * * * \\
(11.04)\end{array}$ & & $\begin{array}{c}0.110 * * * \\
(12.74)\end{array}$ & \\
\hline Control Variables & Yes & Yes & Yes & Yes \\
\hline Year-Quarter FE & Yes & Yes & Yes & Yes \\
\hline Industry FE & Yes & No & Yes & No \\
\hline Firm FE & No & Yes & No & Yes \\
\hline Firm Clustered SE & Yes & Yes & Yes & Yes \\
\hline \# of Observations & 93,775 & 93,521 & 93,775 & 93,521 \\
\hline Adj. R-Squared & 0.336 & 0.762 & 0.608 & 0.902 \\
\hline
\end{tabular}

Notes: This table reports results from placebo tests based on a placebo date, where the placebo date is September 22, 2012. The sample period is from September 22, 2009 to September 21, 2015. Post_Placebo is an indicator variable that equals one if the observation is in the placebo post-treatment period (i.e., from 9/22/2012 to 9/21/2015) and zero otherwise. In the firm fixed effects specification, singleton firms (i.e., firms with only one observation in the sample) are dropped to avoid underestimating standard errors and overstating statistical significance (Correia 2015; deHaan et al. 2017). The $t$-statistics reported in parentheses are based on standard errors clustered by firm. Appendix B contains variable definitions. 
Table 12

Placebo Tests: Unaffected Institutional Investors

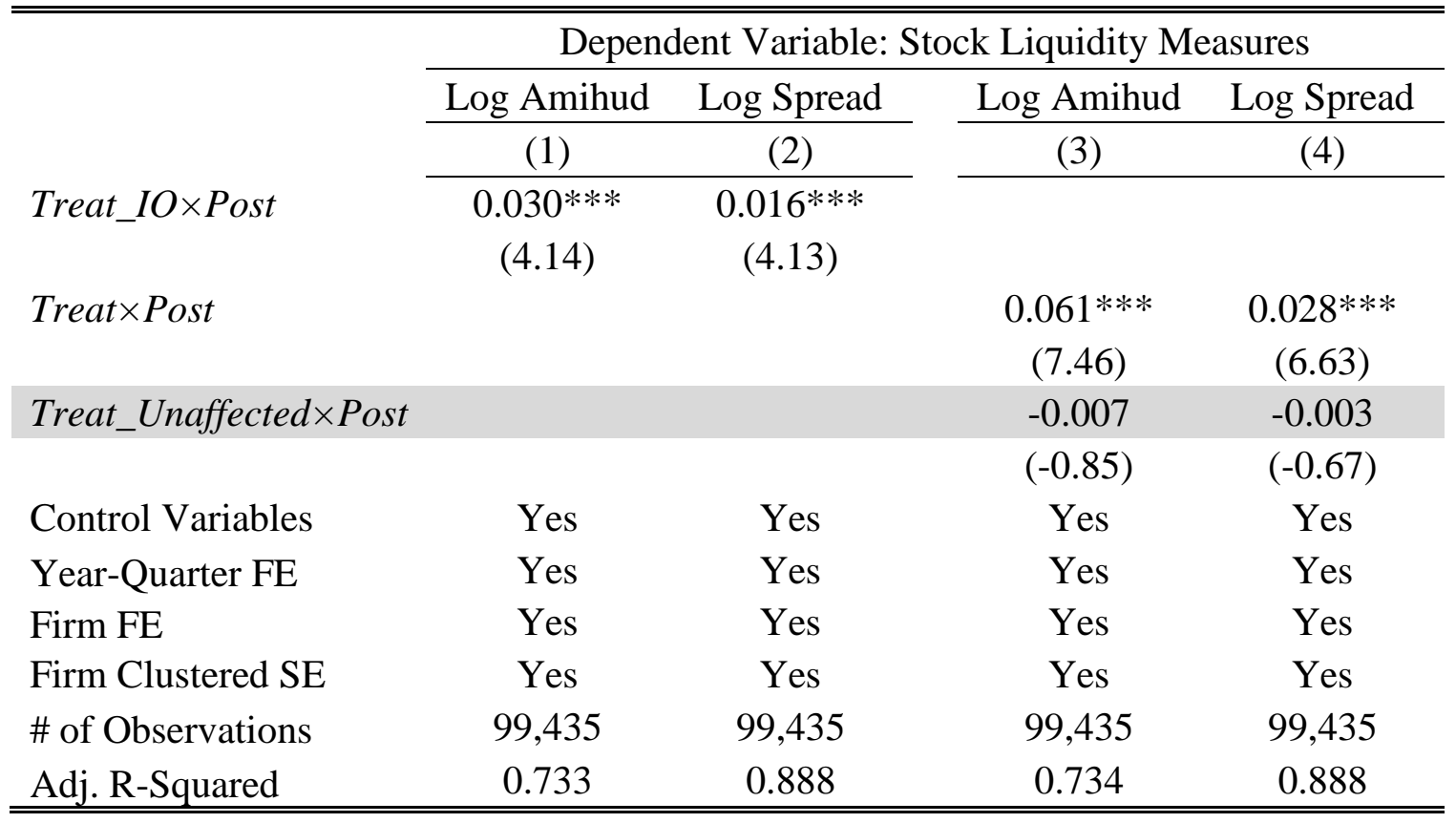

Notes: This table reports results from placebo tests based on ownership unaffected by the SEC proposal. Treat_IO is an indicator variable that equals one if total institutional ownership (including mutual fund ownership) in the quarter immediately before September 22, 2015 is more than the median total institutional ownership and zero otherwise. Treat_Unaffected is an indicator variable that equals one if unaffected ownership in the quarter immediately before September 22, 2015 is more than the median unaffected ownership and zero otherwise, where unaffected ownership equals total institutional ownership minus mutual fund ownership. In the firm fixed effects specification, singleton firms (i.e., firms with only one observation in the sample) are dropped to avoid underestimating standard errors and overstating statistical significance (Correia 2015; deHaan et al. 2017). The $t$-statistics reported in parentheses are based on standard errors clustered by firm. Appendix B contains variable definitions. 


\section{Table 13}

Robustness Check: Controlling for Mutual Fund Ownership

\begin{tabular}{|c|c|c|c|c|}
\hline & \multicolumn{4}{|c|}{ Dependent Variable: Stock Liquidity Measures } \\
\hline & \multicolumn{2}{|c|}{ Log Amihud } & \multicolumn{2}{|c|}{ Log Spread } \\
\hline & $(1)$ & (2) & (3) & (4) \\
\hline Treat $\times$ Post & $0.049 * * *$ & $0.058 * * *$ & $0.019 * * *$ & $0.027 * * *$ \\
\hline & $(5.48)$ & $(7.95)$ & (4.13) & $(7.24)$ \\
\hline Treat & $\begin{array}{c}0.206 * * * \\
(13.70)\end{array}$ & & $\begin{array}{c}0.133 * * * \\
(12.82)\end{array}$ & \\
\hline Mutual Fund Ownership & $\begin{array}{l}0.010 \\
(1.27)\end{array}$ & $\begin{array}{c}-0.0001 \\
(-0.26)\end{array}$ & $\begin{array}{l}0.036 \\
(1.14)\end{array}$ & $\begin{array}{l}0.004 \\
(1.09)\end{array}$ \\
\hline Control Variables & Yes & Yes & Yes & Yes \\
\hline Year-Quarter FE & Yes & Yes & Yes & Yes \\
\hline Industry FE & Yes & No & Yes & No \\
\hline Firm FE & No & Yes & No & Yes \\
\hline Firm Clustered SE & Yes & Yes & Yes & Yes \\
\hline \# of Observations & 99,772 & 99,435 & 99,772 & 99,435 \\
\hline Adj. R-Squared & 0.283 & 0.734 & 0.571 & 0.888 \\
\hline
\end{tabular}

Notes: This table reports results from robustness tests where mutual fund ownership is added. Mutual Fund Ownership is the ownership held by mutual funds in the concurrent quarter. In the firm fixed effects specification, singleton firms (i.e., firms with only one observation in the sample) are dropped to avoid underestimating standard errors and overstating statistical significance (Correia 2015; deHaan et al. 2017). The $t$-statistics reported in parentheses are based on standard errors clustered by firm. Appendix B contains variable definitions. 